\title{
Spatial and Temporal Variation of Sea Ice Geophysical Properties and Microwave Remote Sensing Observations: The SIMS'90 Experiment
}

\author{
D.G. BARBER, ${ }^{1}$ D.G. FLETT, ${ }^{1}$ R.A. De ABREU ${ }^{1}$ and E.F. LeDREW ${ }^{1}$
}

(Received 3 April 1991; accepted in revised form 29 October 1991)

\begin{abstract}
In this paper we present results from a sea ice field experiment conducted coincidentally with overflights of orbital and aerial remote sensing instrumentation in Resolute Passage and Barrow Strait, Northwest Territories, Canada. Our principal focus is to describe the spatial and temporal distribution of selected geophysical variables in the context of how microwave energy interacts with this seasonally varying snow-covered sea ice surface. Over the duration of the experiment, snow crystal size, structure, and snow volume salinities changed sufficiently to affect synthetic aperture radar (SAR) scattering; thermal profiles through the snow cover were diurnally driven; ice surface microscale roughness increased due to sublimation of water vapour from the snow pack onto the ice surface; and bulk ice salinities did not change. Results from the SAR data analysis indicate that the geophysical structure of multiyear ice created a larger and more rapid change in the seasonal SAR scattering signature than did the structure for early consolidated smooth first-year ice. These results are considered fundamental to measurement and monitoring of the seasonal evolution of the snow-covered arctic sea ice surface using SAR remote sensing.
\end{abstract}

Key words: snow, sea ice, synthetic aperture radar, seasonal evolution, remote sensing

RÉSUMÉ. On présente dans cet article les résultats d'expériences sur le terrain portant sur la glace marine, menées parallèlement à des survols d'appareils de télédétection en orbite ou aéroportés, dans la baie Resolute et le détroit de Barrow (Territoires du Nord-Ouest). Notre objectif principal est de décrire la distribution spatiale et temporelle de variables géophysiques choisies, en considérant la façon dont l'énergie micro-onde réagit avec la surface de glace marine couverte de neige et qui varie avec les saisons. Pendant la durée des expériences, la taille des cristaux de neige, leur structure et la salinité du volume nival ont changé suffisamment pour influer sur la diffusion du radar à antenne synthétique (RAAS); les profils thermiques à travers le couvert nival suivaient un rythme diurne; la rugosité à petite échelle de la surface de la glace augmentait par suite de la sublimation de la vapeur d'eau venant de la neige qui y était accumulée; et la salinité de la masse de glace n'était pas modifiée. Les résultats de l'analyse des données recueillies avec le RAAS montrent que la structure géophysique de la glace de plusieurs années créait un changement plus important et plus rapide dans la signature saisonnière de la diffusion du RAAS, que ne le faisait la structure de la glace lisse de l'année récemment consolidée. On pense que ces résultats sont très importants pour les mesures et la surveillance, à l'aide de la télédétection au RAAS, de l'évolution saisonnière de la surface de la glace marine arctique recouverte de neige.

Mots clés: neige, glace marine, radar à antenne synthétique, évolution saisonnière, télédétection

Traduit pour le journal par Nésida Loyer.

\section{INTRODUCTION}

Arctic sea ice coverage has a dynamic seasonal extent varying from $15 \times 10^{6} \mathrm{~km}^{2}$ in winter to $8 \times 10^{6} \mathrm{~km}^{2}$ in summer. The alternating presence/absence of sea ice acts as a regulator of chemical and energy fluxes and has significant impacts at all scales. Radiation and energy balances are intimately linked with ice cover, as are the development and sustenance of ecosystems, both marine and terrestrial. The ecological character and diversity of open water areas, particularly those that occur within the perennial ice cover, may act as sensitive indicators of climate variability and ecological change in the Arctic (Stirling, 1980; Dunbar, 1981; LeDrew, 1990).

Due to the inaccessibility of the arctic regions and their sheer vastness, remote sensing in various regions of the electromagnetic spectrum can provide potentially useful information on geophysical aspects of the perennial ice cover. To develop a better understanding of the interrelationships between various sea ice geophysical variables and aspects of the climatology and biology of the ice ecosystem, we have developed a field program called the Seasonal Sea Ice Monitoring Site (SIMS) in Lancaster Sound/Barrow Strait, Northwest Territories (N.W.T.), Canada (Fig. 1). During the 1990 field experiment (SIMS'90) remote sensing data were collected at microwavelengths using an airborne synthetic aperture radar (SAR) sensor (Ice Centre Environment Canada [ICEC] Challenger SAR) contracted from Intera Technologies Ltd. This SAR system is collectively denoted as the Sea Ice and Terrain Assessment Radar (STAR-2). Four orbital sensors provided data in the visible, near infrared, thermal infrared, and at passive microwavelengths (Landsat TM [Thematic Mapper]; SPOT [Systéme pour d'observation de la terre]; the U.S. National Oceanic and Atmospheric Administration AVHRR [Advanced Very High Resolution Radiometer]; and the Defence Meteorological Satellite Program SSM/I [Special Sensor for Microwave/ Imaging] ).

In the SIMS experiment we are attempting to approach monitoring of a seasonal sea ice surface from a systems viewpoint. Conceptually, the research directions are best considered in the context of the linkages within the ocean-ice-atmosphere interface (Fig. 2). Each box in Figure 2 represents a physical variable that affects, and is affected by, the linkages denoted by the flow diagram arrows. Although the central focus here is the snow and ice volume, the schematic denotes the interrelationships through radiative, chemical, mass, and momentum exchanges with the atmosphere and ocean, since these are the main forces acting upon the surface. The processes of interest in SIMS'90 include radiative and energy exchanges, mass and momentum transfer between the ice volume and boundary layer, and ice surface properties, including both presence and absence of ice. Research questions being addressed within SIMS include:

- How does climatological shortwave radiation $\left(\mathrm{K}^{*}\right.$; 0.15-3.0 $\mu \mathrm{m})$ and longwave radiation $\left(\mathrm{L}^{*} ; 3.0-100 \mu \mathrm{m}\right)$ interact with the snow-covered sea ice volume? 


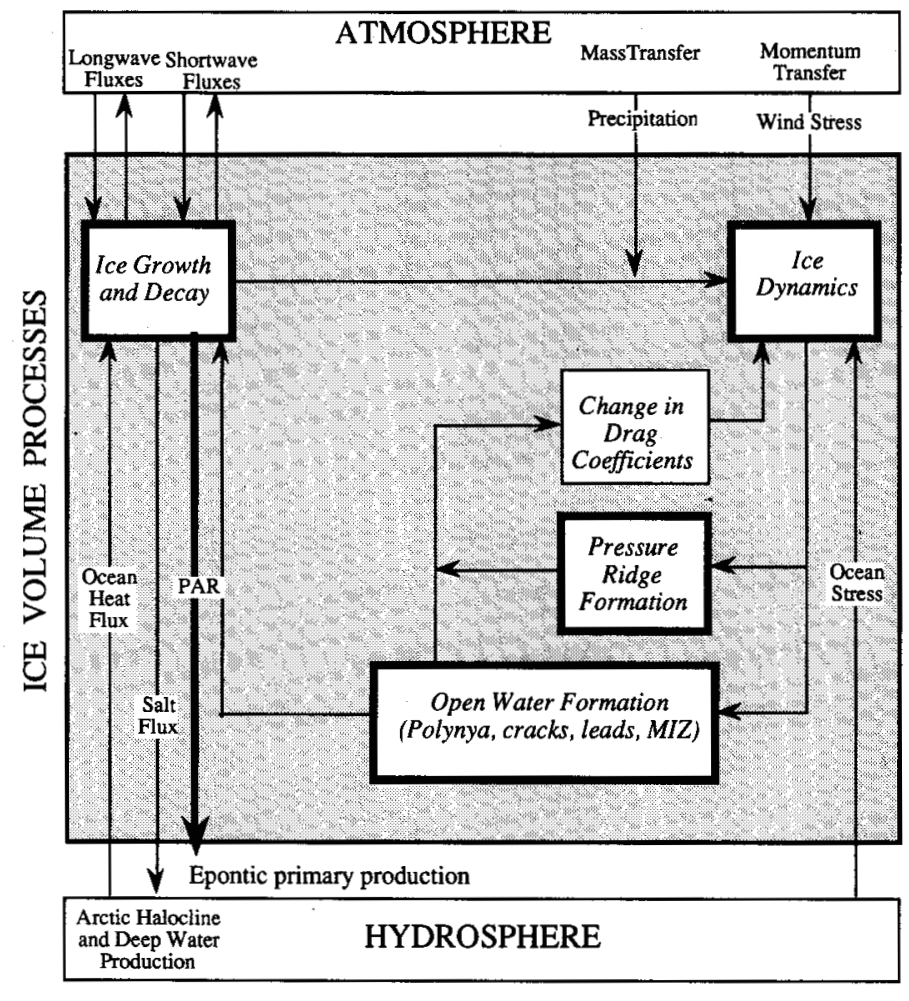

FIG. 2. Schematic of a sea ice volume showing the linkages between the overlaying atmosphere and underlaying hydrosphere. Boxes are variables that are measurable using SAR (Butler, 1987). Details of the physical processes being addressed within SIMS' 90 are described in the text.

(Winebrenner et al., 1989). Dielectric mixing models are used to estimate the average relative dielectric constant from the dielectric constants of the constituent parts (e.g., sea ice consists of brine, ice, air, and perhaps water). A large average dielectric constant results in a less penetrable layer, which means the surface geometry becomes more important in specifying $\sigma^{\circ}$.

An uncalibrated SAR sensor (e.g., STAR-2) provides a relative indication of the scattering return from the sea ice surface in the form of energy backscattered to the SAR antenna. Tone is created in a SAR image by point measurements of the scattering returns measured at the SAR antenna. Texture refers to the spatial variation of tonal elements as a function of scale (Haralick et al., 1973). Within a digital image a homogeneous texture field consists of a spatial arrangement of grey levels that are more homogeneous (as a unit) within than between.

Our principle objective in this paper is to contrast the point measurements and spatial variation of the geophysical variables observed during SIMS'90 within the context of SAR scattering. This information is intrinsically important in developing an understanding of the geophysical processes operating among the atmosphere, ice, and ocean and is considered a prerequisite to developing the capability to measure and monitor these seasonal changes using SAR remote sensing data.

\section{METHODS}

\section{SIMS'90 Site Descriptions}

The SIMS' 90 field sampling program consisted of 23 days of data collection (15 May to 8 June 1990). Field operations were based at the Polar Continental Shelf Project (PCSP) in
Resolute Bay, N.W.T. Four sampling sites were selected after an initial reconnaissance of the fast-ice conditions in Resolute Passage. The sites were identified using visual flagging and were visited daily on a rotating basis throughout the experiment. The four sites were designated (Fig. 3): MYI (multiyear ice), HOME (early consolidated, smooth first-year ice), FYI (first-year ice), and TRANSECT (12.5 km long transit across Resolute Passage). Sites were located so they could be easily accessed by snowmobile from the PCSP base. Through our site selection we attempted to characterize all ice types and features present within the intensive sampling area and facilitate access to various other ice features of interest within the extensive sampling area (Fig. 1).

Ice conditions at the HOME site (Fig. 4A) consisted of smooth first-year ice. The ice at this site consolidated in late September 1989. A rectangular sampling area of approximately $100 \mathrm{~m}$ by $50 \mathrm{~m}$ was identified by corner poles. Two sampling lines along each of the $100 \mathrm{~m}$ sides were roped off. Snow/ice sampling was conducted along one line and surface radiation measurements along the other.

The TRANSECT site was established as a traverse across Resolute Passage from a distinguishable v-knotch valley on Griffith Island heading towards Cape Martyr on Cornwallis Island (Fig. 4B). The ice in this portion of Resolute Passage (Fig. 3) consolidated in late October 1989. Ten sites spaced 1 $\mathrm{km}$ apart were sampled across the transect starting from $1 \mathrm{~km}$ off the shore of Griffith Island. The tenth site was located approximately $2.5 \mathrm{~km}$ from the Cape Martyr shore.

The FYI site was located approximately $6 \mathrm{~km}$ to the southeast of Sight Point near Resolute Bay (Fig. 4C). The FYI site was established on relatively smooth first-year ice about 0.5 $\mathrm{km}$ beyond a moderately rubbled zone of ice running between the southeastern tip of Griffith Island and Prospect Point on Cornwallis Island (Fig. 3). Consolidation time for the FYI site is estimated at late December or early January. A rectangular sampling area was established in the same manner as at the HOME site.

The MYI site was located approximately $6 \mathrm{~km}$ to the southwest of the FYI site in the middle of a $2 \mathrm{~km}$ diameter multiyear floe situated at the edge of a first-year rubble zone (Fig. 3). The site is characterized by alternating hummock and meltpond surface topography (Fig. 4D). Hummocks ranged in height from less than $1 \mathrm{~m}$ to approximately $6 \mathrm{~m}$ over the average surface of the floe. The same rectangular sampling site used at the HOME and FYI sites was established at the MYI site.

\section{Geophysical Data Collection}

Consistent with the systems approach we have implemented within the SIMS project (Fig. 2), we have compartmentalized the atmosphere-ice-ocean within SIMS'90 to allow effective separation of each of the geophysical variables collected (Table 1). For convenience of presentation and discussion, the variables are divided into a vertical criterion of boundary layer, snow, and ice variables. The parameters denoted with an asterisk $\left(^{*}\right)$ in Table 1 were selected for discussion due to their importance in contributing to and/or controlling SAR scattering.

Boundary Layer Variables: A full suite of surface climate measurements and radiosonde data were collected daily at the Atmospheric Environment Services weather station at Resolute Bay (Table 1). Air temperature was measured regularly during in situ sampling using shaded thermocouple probes suspended $1 \mathrm{~m}$ above the surface. A microclimate station 


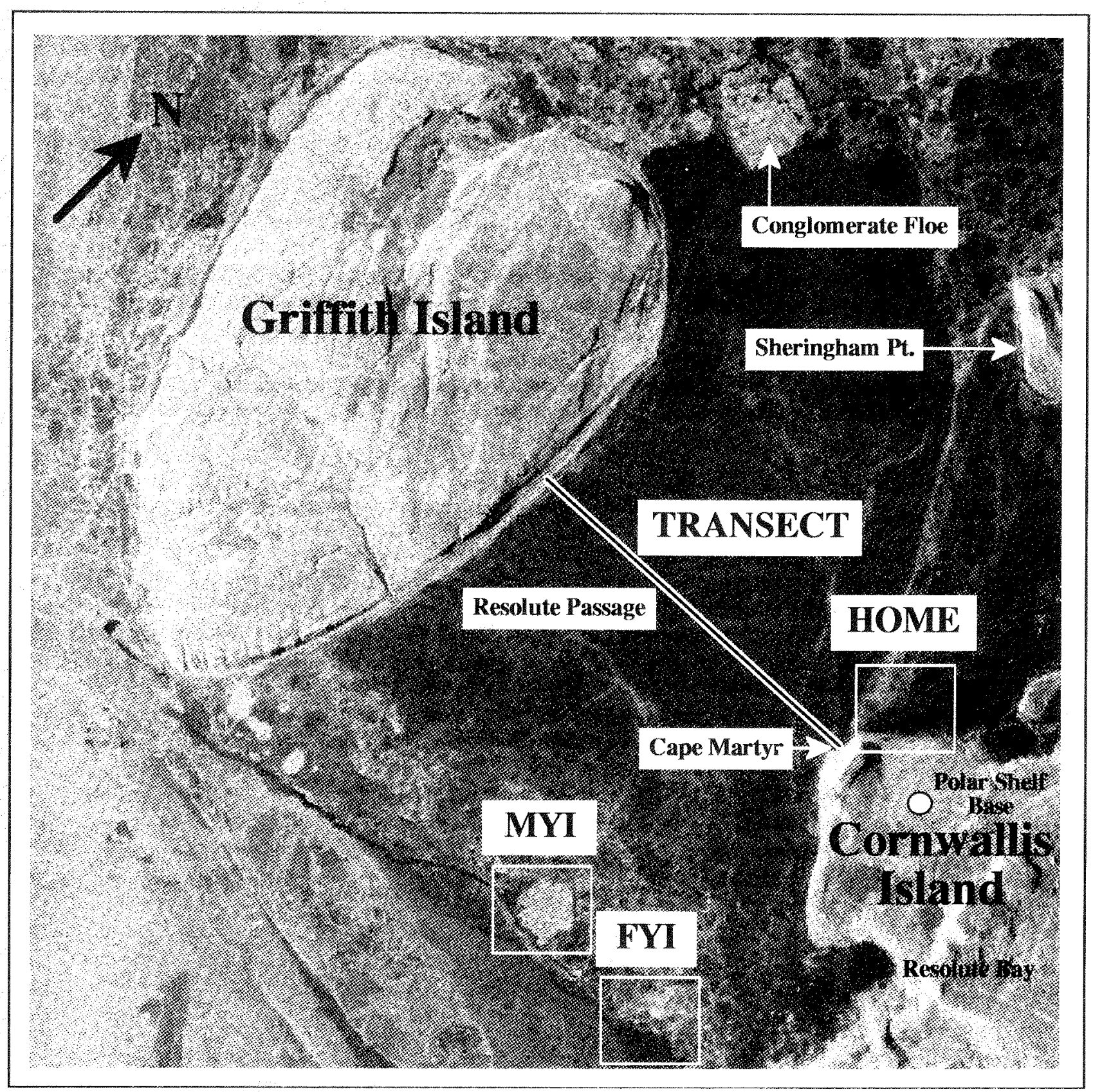

FIG. 3. STAR-2 SAR image of the Seasonal Sea Ice Monitoring Site (SIMS) intensive sampling area. Geographical place names used in the text are denoted, as are the MYI, FYI, HOME, and TRANSECT sampling areas. The actual locations of the surface sample sites within the MYI, FYI, and HOME areas are described in Figures 5A, 6A, and 7A (small opaque squares).

located at the MYI site measured: near-surface temperature and humidity at two levels, net radiation, incoming shortwave radiation, and sub-surface heat flux within the snow volume.

Snow Variables: Snow temperature profiles (Table 1) included ice temperature $(-2.5 \mathrm{~cm}$ into ice), snow/ice interface temperature, snow pack temperatures, snow/air interface temperature, and air temperature. All temperatures were measured using thermocouple probes with digital read-out to a Fluke temperature meter accurate to $0.1 \mathrm{C}^{\circ}$. Snow pack temperatures were collected by inserting the probe $5-10 \mathrm{~cm}$ into the snow along an undisturbed edge of a snow pit. Temperatures were taken at $5 \mathrm{~cm}$ intervals starting $5 \mathrm{~cm}$ above the ice surface and progressing upward. Snow/ice interface temperatures were measured with the probe inserted $5-10 \mathrm{~cm}$ into the snow/hoar layer at the ice surface. Sub-ice temperature was measured by hand drilling approximately $2.5 \mathrm{~cm}$ into the ice and inserting the probe until firm contact was made with the sea ice. Snow depths and hoar depths were measured at each snow pit using a metre stick. Samples of depth hoar (if present) and surface snow were collected and analyzed for salinity using a handheld Atago optical refractometer accurate to $\pm 0.1 \mathrm{ppt}$.

Snow density was measured over the duration of the experiment at all major sites. Densities were acquired using a standard volume from the top snow layer and weighing the sample. The error estimate on this method is approximately $\pm 30 \mathrm{~kg} \cdot \mathrm{m}^{-3}$ (Garrity and Burns, 1988). Snow grain size was 

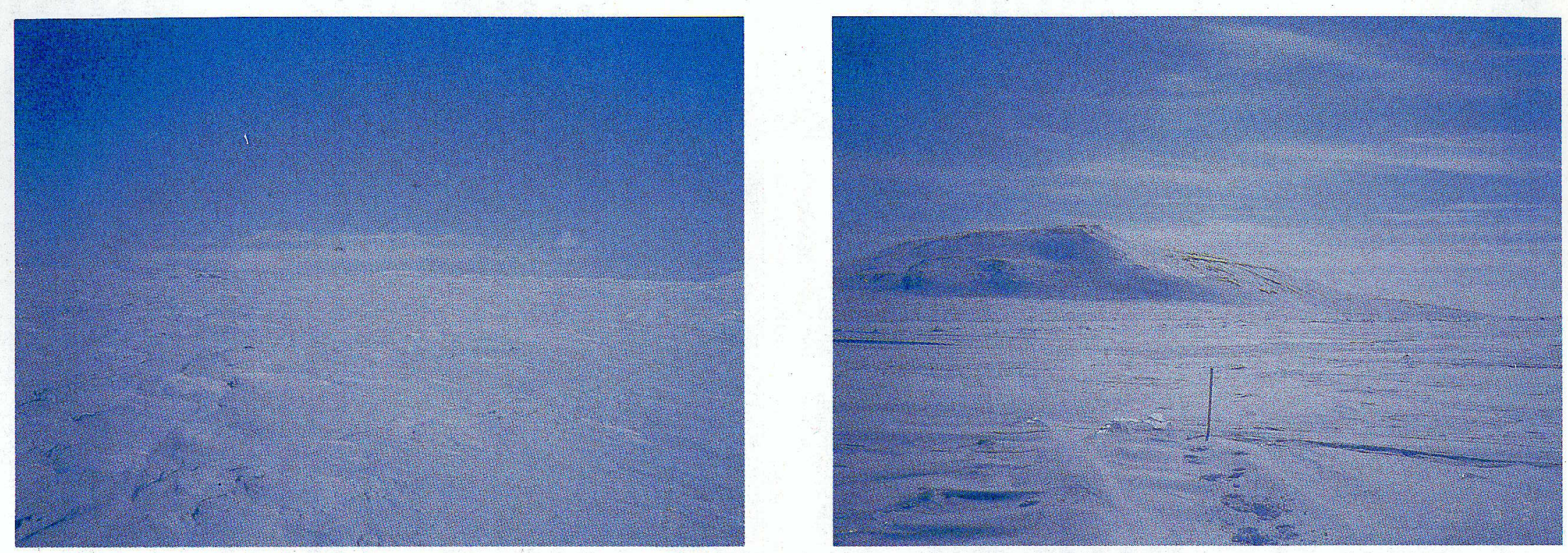

C

D
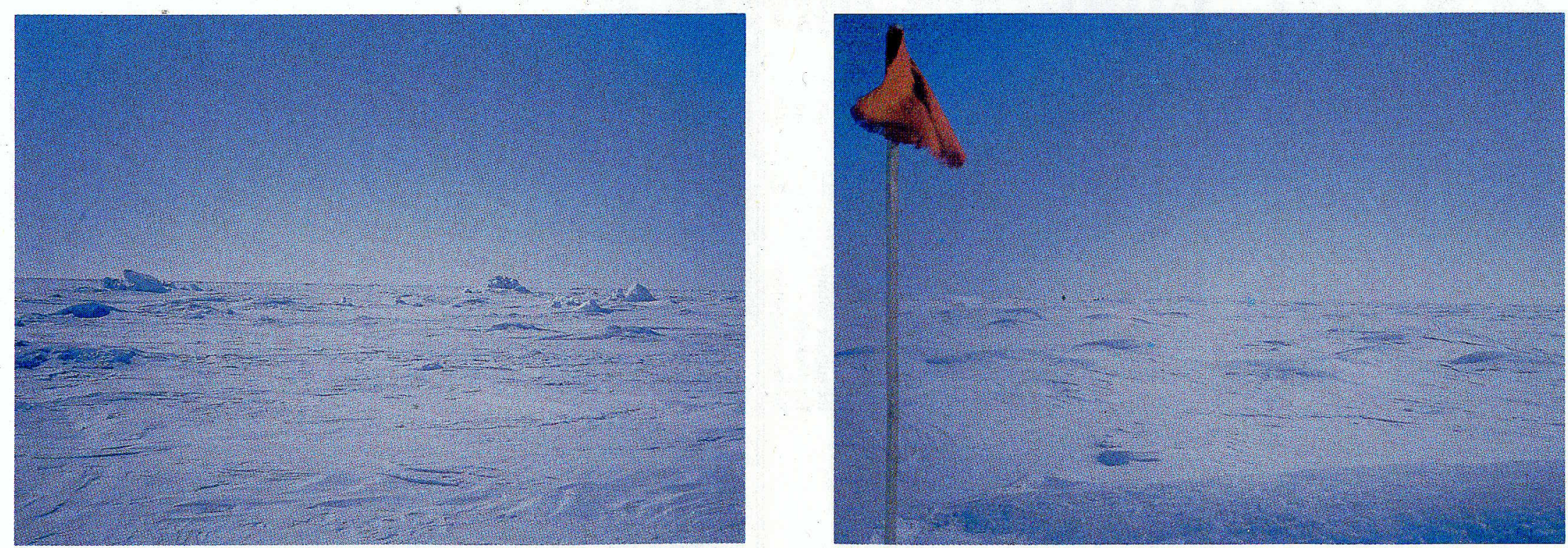

FIG. 4. $35 \mathrm{~mm}$ photos of the four intensive sampling sites. A) HOME site, showing the snow surface conditions looking north and west from the sample site; B) TRANSECT site, showing the snow surface conditions looking east across Resolute Passage towards Cape Martyr; C) FYI site, showing the snow surface conditions and the first-year ice rubble conditions north of the site; D) MYI site, showing the surface of the hummocks and snow-covered melt ponds (flags were used to denote the corner of the sampling area). 
TABLE 1 . Summary of geophysical data collected during SIMS' 90

\begin{tabular}{|c|c|c|c|c|c|c|}
\hline Vertical layer & & Symbol & Units & Instrument/data collection & Spatial coverage & Temporal coverage \\
\hline \multicolumn{7}{|c|}{ Boundary layer variables } \\
\hline & Cloud type & - & type & Resolute Bay weather station & Resolute Bay & Daily \\
\hline & Cloud amount & - & tenths & " & " & " \\
\hline & Cloud opacity & - & tenths & $"$ & " & " \\
\hline & Sea level pressure & - & $\mathrm{kPa}$ & $"$ & $"$ & $"$ \\
\hline & Air temperature ${ }^{*}$ & - & ${ }^{\circ} \mathrm{C}$ & $"$ & $"$ & $"$ \\
\hline & Precipitation ${ }^{*}$ & - & $\mathrm{cm}$ & $"$ & $"$ & $"$ \\
\hline & Dewpoint temp. & - & ${ }^{\circ} \mathrm{C}$ & $"$ & $"$ & $"$ \\
\hline & Visibility & - & miles & $"$ & $"$ & $"$ \\
\hline & Water equivalent & - & $\mathrm{mm}$ & " & " & " \\
\hline & Wind direction & - & degrees & $"$ & $"$ & $"$ \\
\hline & Wind speed & - & & $"$ & $"$ & $"$ \\
\hline & $\begin{array}{l}\text { Incident shortwave } \\
\text { Radiation }\end{array}$ & $\mathrm{K} \downarrow$ & $\mathrm{W} \cdot \mathrm{m}^{-2}$ & $\begin{array}{l}\text { Pyranometer } \\
\text { (0.3-3.0 micrometres) }\end{array}$ & All sites & Exp/selected days \\
\hline \multicolumn{7}{|c|}{ Snow variables } \\
\hline & Snow temp. profiles* & - & ${ }^{\circ} \mathrm{C}$ & Temperature probe & All sites & Exp/selected days \\
\hline & Snow depth & - & $\mathrm{cm}$ & Metre stick & " & Exp/selected days \\
\hline & Hoar depth" & - & $\mathrm{cm}$ & Metre stick & " & Day $13 /$ selected days \\
\hline & Hoar salinity" & - & ppt & Optical salinometer/refractometer & $"$ & Day $13 /$ selected days \\
\hline & Snow density* & - & $\mathrm{kg} \cdot \mathrm{m}^{-3}$ & Weight/volume sampling & $"$ & Exp/selected days \\
\hline & Snow wetness & - & $\%$ & Resometer & " & Day $7 /$ selected days \\
\hline & Snow grain size ${ }^{*}$ & - & $\mathrm{mm}$ & Visual measurement & " & Day $7 /$ selected days \\
\hline & Albedo & $\alpha$ & $0-1.0$ & Pyranometer & $"$ & Exp/selected days \\
\hline & Reflectance ${ }^{*}$ & $\rho$ & $0-1.0$ & Spectroradiometer & FYI, MYI & Day $10 /$ selected days \\
\hline & Net radiation & $\mathrm{Q}^{*}$ & $\mathrm{~W} \cdot \mathrm{m}^{-2}$ & Net pyrradiometer & All sites & Exp/selected days \\
\hline & Permittivity & $\varepsilon^{\prime}$ & $-\cdots$ & Reșometer & & Exp/selected days \\
\hline \multicolumn{7}{|l|}{ Ice variables } \\
\hline & Ice temp. profiles" & - & ${ }^{\circ} \mathrm{C}$ & Core auger/temperature probe & All sites & Exp/selected days \\
\hline & Ice salinity profiles ${ }^{*}$ & - & $\mathrm{ppt}$ & Optical salinometer/refractometer & & \\
\hline & Ice surface salinity ${ }^{*}$ & - & ppt & Optical salinometer/refractometer & All sites & Day $8 /$ selected days \\
\hline & Ice thickness & - & $\mathrm{cm}$ & Drill auger & FYI, MYI, TRANSECT & Exp/selected days \\
\hline & Surface roughness ${ }^{*}$ & $\sigma_{\mathrm{h}}$ & $\mathrm{mm}$ & Surface roughness meter & All sites & Exp/selected days \\
\hline
\end{tabular}

*Indicates variables discussed in text (Methods and Results).

Daily - indicates variable measured every day over entire experiment period (and beyond).

Exp/selected days - indicates variable measured over entire experiment period on selected days.

Day $\mathrm{x} / \mathrm{selected}$ days - indicates variable measured from day $\mathrm{x}$ to end of experiment period on selected days.

visually estimated to the nearest millimetre using gridded graph paper. Snow wetness was inferred from permittivity measurements recorded by a field resometer (Garrity, 1990).

Surface reflectivity was characterized at all sites by measuring climatological (integrated) and spectral albedo. Integrated measurements were obtained with a Middleton albedometer $(0.30-3.0 \mu \mathrm{m})$ and spectral measurements with an SE-590 radiometer $(0.38-1.2 \mu \mathrm{m})$. Spectral albedos required use of a barium sulphate reference panel for measurement of the incident solar irradiance.

Ice Variables: Ice profiles included salinity and temperature measurements from vertical profiles of ice cores. Cores were extracted using a gas-powered coring auger. Cores were drilled and analyzed immediately after they were extracted. Salinity samples were taken starting at the top (ice surface) and progressing downward at $10 \mathrm{~cm}$ intervals to the bottom of the core. Salinity samples were also taken from the top $5 \mathrm{~mm}$ of the ice surface at the pits where snow variables were measured. All samples were analyzed at PCSP base using a handheld Atago optical refractometer. In order to take temperature measurements of the ice, a hole was either chipped or drilled into the core and a thermocouple probe inserted. The thermocouple probes were output to a Fluke meter. All attempts were made to measure the ice temperatures immediately after coring to avoid ambient temperature contamination.

Ice depth and freeboard were recorded periodically by drilling holes with a gas-powered drill auger ( $4^{\prime \prime}$ diameter and $6 \mathrm{~m}$ of drill flights) and using weighted measuring tapes. It should be noted that ice depths at the MYI site occasionally exceeded $6 \mathrm{~m}$.

Micro-scale roughness was characterized using a prototype instrument called the Surface Roughness Meter (SRM). Micro-scale roughness is defined as the millimetre to centimetre scale changes in the vertical relief of the surface. The two surface roughness parameters obtained are rms height $\left(\sigma_{\mathrm{h}}\right)$ and correlation length $(\mathrm{L})$. The instrument illuminates a rectangle of known dimension onto the surface. This illumated area is then photographed. The photographs are digitized into a microcomputer and point estimates of $\sigma_{h}$ and $L$ are obtained from specialized analysis software (Paterson, 1990).

\section{Synthetic Aperture Radar Data Collection}

Although remote sensing data were collected over a range of frequencies of the electromagnetic spectrum, we focus here on only one sensor, the synthetic aperture radar (SAR). SAR data were collected by the Sea ice and Terrain Assessment Radar-2 (STAR-2) system during the SIMS'90 experiment. The sensor consists of two X-band $(9.3 \mathrm{GHz}), \mathrm{HH}$-polarized SARs mounted to image left and right of track from a Challenger jet aircraft. This uncalibrated SAR system provides millions of square kilometres of sea ice data to the Ice Centre Environment Canada, where it is used operationally in mapping ice conditions in Canadian arctic and subarctic waters. SAR image data were collected over the SIMS site on three 
different dates (Table 2) spanning the seasonal conditions of winter, early melt, and melt onset.

Each STAR-2 swath used was checked to ensure that each contained a full 8 bit range of grey levels prior to extracting the digital numbers (Dn). The STAR-2 radar logs were obtained for the four datasets used here (Table 2): sensitivity time control (STC) was set to ice; the processor gain (RTP gain) and transmitted power were approximately consistent; and the IF gain ranged by only $\pm 0.05 \mathrm{~dB}$. In this configuration the settings are considered sufficiently consistent to allow qualitative comparison of the Dn distributions across the three seasons.

Sub-images coincident with the SIMS study area $(2048 \times$ 2048 pixels) were extracted from each of the large (4096 pixels by $\sim 50000$ lines by 256 grey levels) SAR data sets. A 256 $\times 256$ sub-area was then extracted for the MYI, HOME, and FYI sites (Fig. 3) from the winter (29 January), early melt (23 May), and melt onset (13 June) data (Figs. 5A, 6A, and 7A).

Digital numbers $(\mathrm{Dn})$ were extracted from $50 \times 50$ pixel sub-areas ( $c f$. Figs. 5A, 6A, and 7A) approximately coincident with the SIMS'90 sampling sites (MYI, HOME, and FYI). Percentile line diagrams of the grey levels were produced to evaluate the direction and magnitude of change in scattering to the SAR throughout the seasonal evolution of the surface. A non-parametric test of the distributional differences of the grey level values within each site over the three sea ice seasons was conducted using a Friedman test. The magnitude of the differences between each of the three grey level distributions within each site is represented by the chi-squared statistic provided in Figures 5A, 6A, and 7A. The percentile plots describe the average, variance, and skewness of the more familiar histogram representation of the Dn distributions. Higher variance results in a larger slope. Tails of the histogram are represented in the upturned (and downturned) tails of the percentile plot and the various percentiles of the distribution can be read directly from the abscissa (Figs. 5A, 6A, and 7A). Caution is warranted when assigning significance to observed differences in the $\mathrm{Dn}$ distributions, since sensor and imaging geometry can cause changes in the average scattering recorded by the radar.

Grey Level Co-occurrence Matrix (GLCM) texture transformations were computed for ten $25 \times 25$ sub-areas in the immediate vicinity of the MYI, HOME, and FYI sites (Figs. $5 \mathrm{~B}, 6 \mathrm{~B}$, and $7 \mathrm{~B}$ ). A GLCM consists of a matrix that provides the conditional joint probabilities of all pairwise combinations of pixels within a computation window $\left(\dot{W}_{n m}\right)$. The co-occurrence of grey levels represents the probability of any two pairs of grey levels occurring, conditional on the interpixel sampling distance $(\delta)$ and orientation $(\alpha)$ used for computation. Algebraically this can be expressed as [2] where $\mathrm{C}_{\mathrm{ij}}$ is defined in [3] following Haralick et al. (1973) and Barber and LeDrew (1991).

$$
\operatorname{Pr}(\mathrm{x})=\left\{\mathrm{C}_{\mathrm{ij}} \mid \delta, \alpha\right\}
$$

TABLE 2. Characteristics of the STAR-2 sub-images coincident with the SIMS' 90 field validation site

\begin{tabular}{lccccc}
\hline \hline Date & $\begin{array}{c}\text { Time } \\
\text { (local) }\end{array}$ & $\begin{array}{c}\text { Flight } \\
\text { dir. }\end{array}$ & $\begin{array}{c}\text { Look } \\
\text { dir. }\end{array}$ & $\begin{array}{c}\text { Look angle } \\
\text { near-far }\end{array}$ & $\begin{array}{c}\text { Temp. } \\
\left({ }^{\circ} \mathrm{C}\right)\end{array}$ \\
\hline $29 / 01 / 90$ & $12: 51$ & East & North & $60.0-71.2^{\circ}$ & -30 \\
$23 / 05 / 90$ & $11: 35$ & West & North & $66.7-78.2^{\circ}$ & -16 \\
$13 / 06 / 90$ & $08: 18$ & West & North & $64.3-75.5^{\circ}$ & -3.0 \\
\hline \hline
\end{tabular}

$$
C_{i j}=\frac{P_{i j}}{\sum_{i j=1}^{n} P_{i j}}
$$

where $P_{i j}$ is the frequency of occurrence of grey levels $i$ and $j$. Summation over $\mathrm{n}$ refers to the total number of pixel pairs, which is dependent on the parameter $\delta$ and the subscripts $n$ and $\mathrm{m}$ from $\mathrm{W}_{\mathrm{nm}}$. In the following analysis an eight bit image (256 grey levels) has been quantized to four bits (16 grey levels) to reduce computation time. Texture statistics are computed from the matrix and represent a single spatial measure of the image texture from which the GLCM was computed. Contrast is a summary statistic of the GLCM and indicates the single measure of texture used here [4].

$$
\sum_{i=1}^{n} \sum_{j=1}^{n} C_{i j}(i-j)^{2}
$$

Comparison of the GLCM Contrast statistic distributions at each site within each season was conducted using boxplots. A parametric Multivariate Analysis of Variance (MANOVA) was conducted on the texture data (Contrast statistics) extracted from each of the sites in Figures 5B, 6B, and 7B. The assumption of homoscedasticity was tested using Hartley's test for equal sample sizes and resulted in a square root transform being applied to the Contrast [4] distributions. A post hoc test was conducted on the square root transformed Contrast distributions [4] to determine the statistical separation of the ice sites and season factor means. This analysis was computed for all pairwise combinations of factor levels at a specific level of the other main factor. All statistical analyses were conducted using algorithms described in Barber (1989) and using SYSTAT (Wilkinson, 1989). Comparison of GLCM Contrast statistics, obtained from the STAR-2 data, may be assessed quantitatively, since the algorithms used are invariant to monotonic transformation of the digital data.

\section{RESULTS AND DISCUSSION}

\section{Geophysical Data}

Boundary Layer Variables: During SIMS'90, incoming shortwave measurements at the MYI site indicated a diurnal minimum of $25 \mathrm{~W} \cdot \mathrm{m}^{-2}$ ( 29 May) and a recorded maximum of $880 \mathrm{~W} \cdot \mathrm{m}^{-2}$ (6 June). During SIMS' 90 , the temperature ranged from a low of $-17.8^{\circ} \mathrm{C}$ to a high of $0^{\circ} \mathrm{C}$. The mean hourly temperature recorded in the first half of SIMS'90 (15-26 May) was $-9.6^{\circ} \mathrm{C}$. In the latter half of the experiment ( 27 May -13 June) the mean hourly air temperature increased to $-3.44^{\circ} \mathrm{C}$. Hourly air temperatures over the experiment period (Fig. 8) displayed a distinctive diurnal pattern. The temperature often reached its daily maximum in the late afternoon (approximately $1800 \mathrm{~h}$ ). Daily temperature ranges were large in the first half of SIMS' $90\left(8-10 C^{\circ}\right)$ compared to those recorded in the latter half of the experiment $\left(2-6 \mathrm{C}^{\circ}\right)$. Air temperatures recorded at the MYI site were very similar to those recorded at the Resolute Bay weather station.

Precipitation increased throughout the experiment. Although often localized, measurements of water equivalent precipitation (most likely snow) recorded at Resolute Bay showed a dramatic increase in the latter stages of the experiment. The advection of moisture from the approaching ice 
edge in Lancaster Sound, east of the experiment sites (Fig. 1), is likely responsible.

Snow Variables: Snow temperature profiles at selected sampling points along each site transect are plotted for the mid-period of the field program to illustrate their spatial variation (Fig. 9). In most cases, the trend in the temperature gradients are negative (warm to cold) from the air through to the ice. Air temperature controls the shape of the temperature profiles to some degree. If air temperatures were cold and similar to ice temperatures, then the gradients were near isothermal (Fig. 9C - FYI Site, 29 May). Variations in individual snow temperature profiles within a site were largest at the MYI site due to the variability in the snow depth overlying the ice. With little or no snow cover (on hummocks), temperature profiles were isothermal (Fig. 9A - MYI Site, 28 May). Snow temper- ature profiles varied to a small degree over the experiment period at each site. Air temperature was the controlling factor. Air temperatures were low at the start of the field experiment and rose to a maximum around 2 June, after which temperatures began to fall slightly (up to 7 June; Fig. 8). This was reflected in the snow temperature profiles over the 23-day period. Ice temperatures showed a very gradual rising trend over the field program. This produced an increasing trend towards near-isothermal snow profiles as the field program progressed. Exceptions from this trend occurred during the cold and warm periods described above. Mean snow depth was largest at the MYI site (Table 3) and ranged from $0 \mathrm{~cm}$ on hummocks to a maximum of $147 \mathrm{~cm}$ on melt ponds. Snow depths over all sites did not vary significantly over the extent of the field program (Fig. 10).

\section{A}

\section{Tone Images MYI Site}

\section{Winter}

- January 29, 1990, 12:51 hrs.
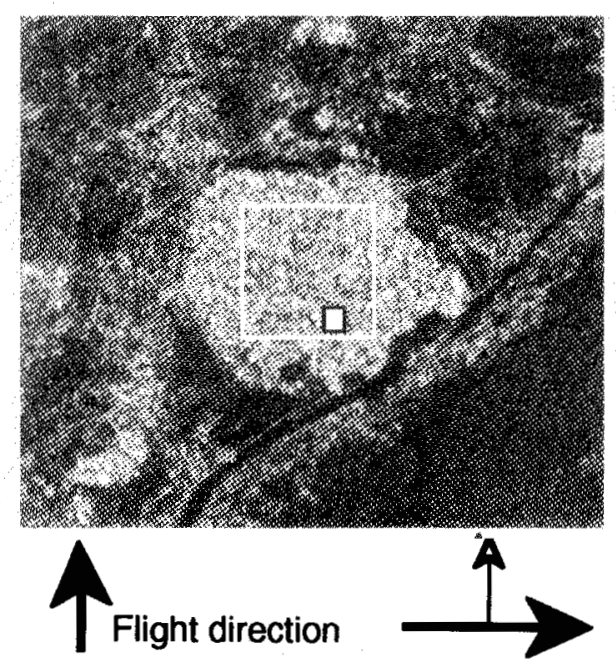

A Look direction.

\section{Early Melt}

May 23, 1990, 11:35 hrs.
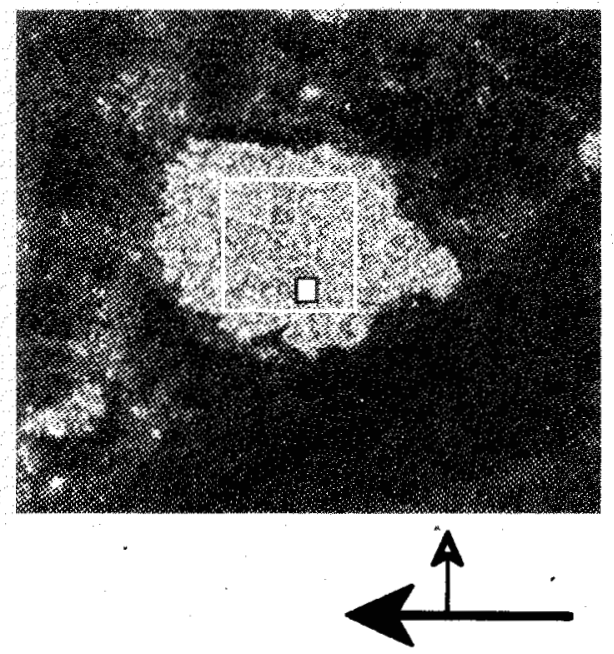

Melt Onset June 13, 1990, 08:18 hrs.
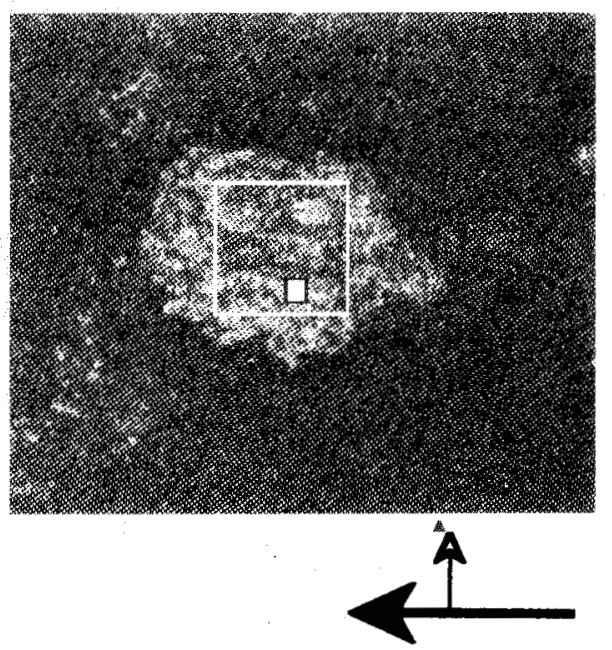

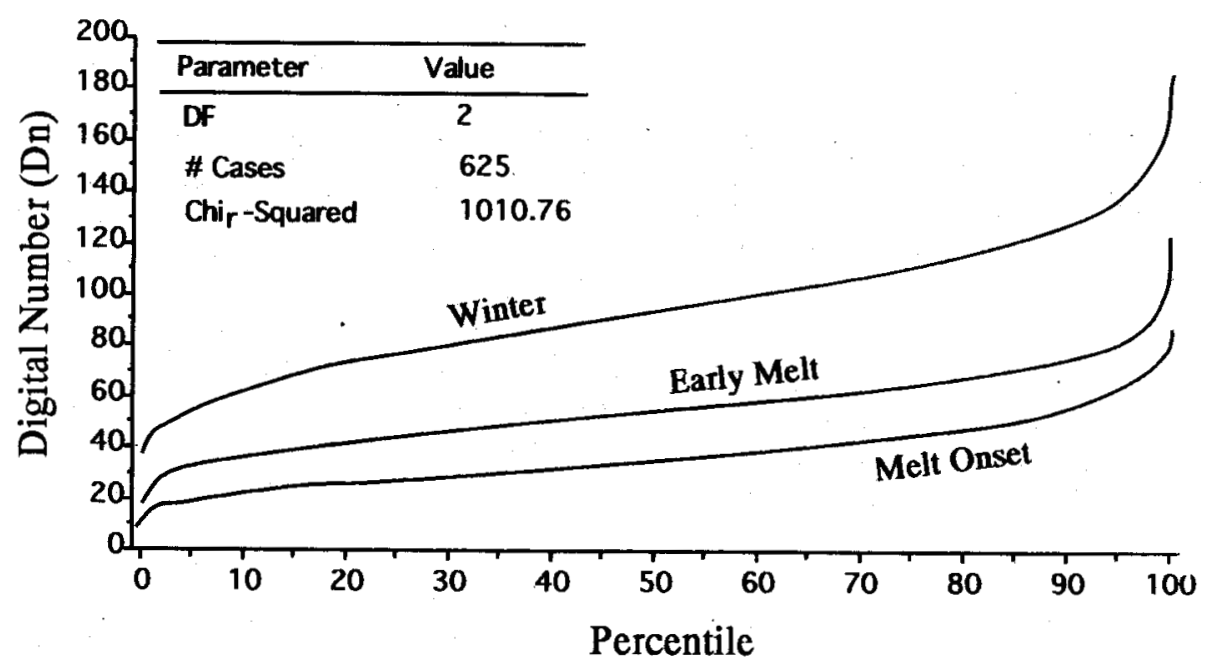

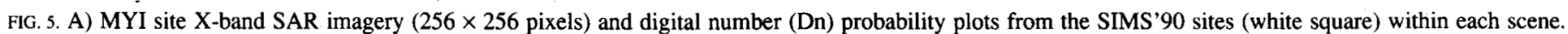

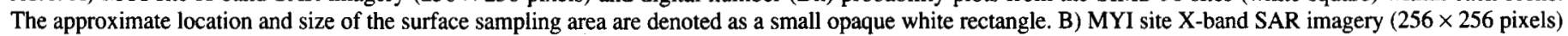

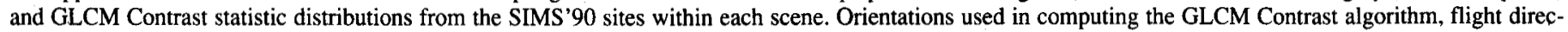
tion, and look direction of the SAR are denoted. 
Hoar depth at the MYI site had a mean value of $4.7 \mathrm{~cm}$, while at the first-year sites (HOME, FYI, and TRANSECT) the mean value was $3.9 \mathrm{~cm}$. Hoar depth did not vary significantly over the duration of the field program and did not appear until halfway through the experiment period (approximately 26-28 May; Fig. 11). This period coincides approximately with the rise in air temperatures towards $0^{\circ} \mathrm{C}$ and may have resulted in hoar formation due to development of thermal and vapour gradients between the atmosphere and ice. Hoar salinities were higher at the first-year ice sites (HOME, FYI, and TRANSECT) than at the MYI site (Figs. 11A and 11B). Mean hoar salinity values over the entire field program were $3.1 \mathrm{ppt}$ and $12.8 \mathrm{ppt}$ for the MYI site and the FYI sites respectively.

Over SIMS'90, snow density means ranged from $271 \mathrm{~kg} \cdot \mathrm{m}^{-3}$ $\left(\mathrm{SD}=26 \mathrm{~kg} \cdot \mathrm{m}^{-3}\right)$ for the MYI site to $354 \mathrm{~kg} \cdot \mathrm{m}^{-3}\left(\mathrm{SD}=51 \mathrm{~kg} \cdot \mathrm{m}^{-3}\right)$ for the HOME site. Snow density was variable within sites and less variable between sites. Over the experiment period no significant change in snow density was observed.

Like snow density, grain size is strongly affected by seasonal snow metamorphism. Snow grains lose all crystalline features and become rounded as melt-freeze cycles begin in the snow volume. For all sites, snow layers had predominantly rounded grains ranging from 1 to $5 \mathrm{~mm}$. Grain size increased with depth; the largest increase $(10-20 \mathrm{~mm})$ was found in depth hoar layers located at the snow-ice interface. Snow grain size appeared to be geographically independent. SIMS' 90 measurements indicate no discernible temporal trend in snow grain size. Crystals within the snow cover were predominated by rounded shapes. Crystals within the hoar layer at the snow-ice interface primarily consisted of needle and capped columnar shapes.

Spatial and temporal variability of the integrated albedo measurements collected from the MYI and FYI sites (Fig. 12)

\section{Contrast Images MYI Site}

Winter

January 29, 1990, 12:51 hrs.
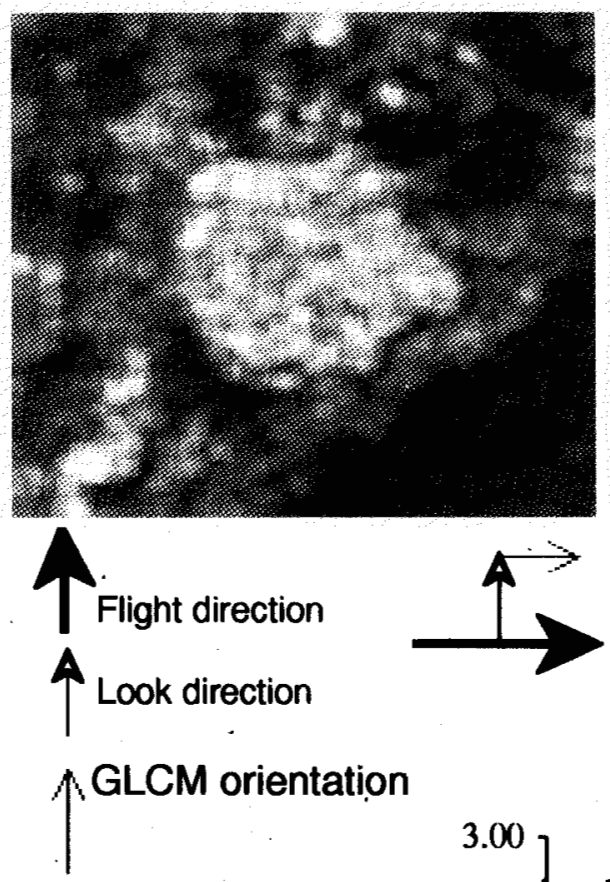

\section{Early Melt}

May 23, 1990, 11:35 hrs.
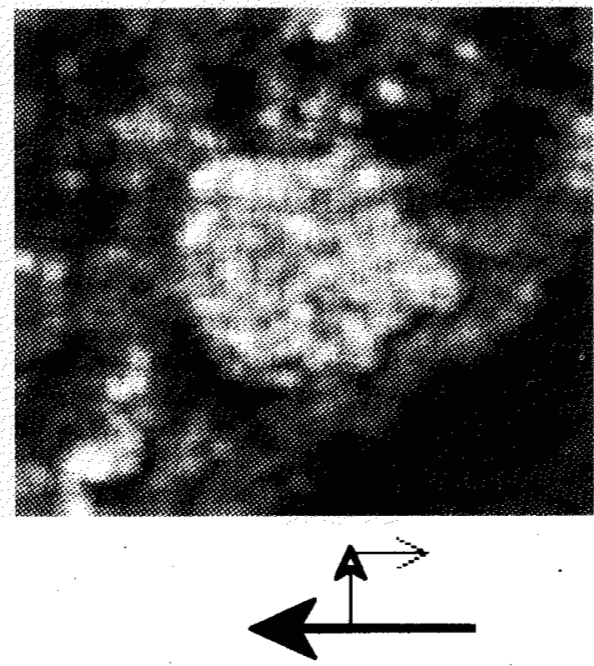

\section{Melt Onset}

June 13, 1990, 08:18 hrs.
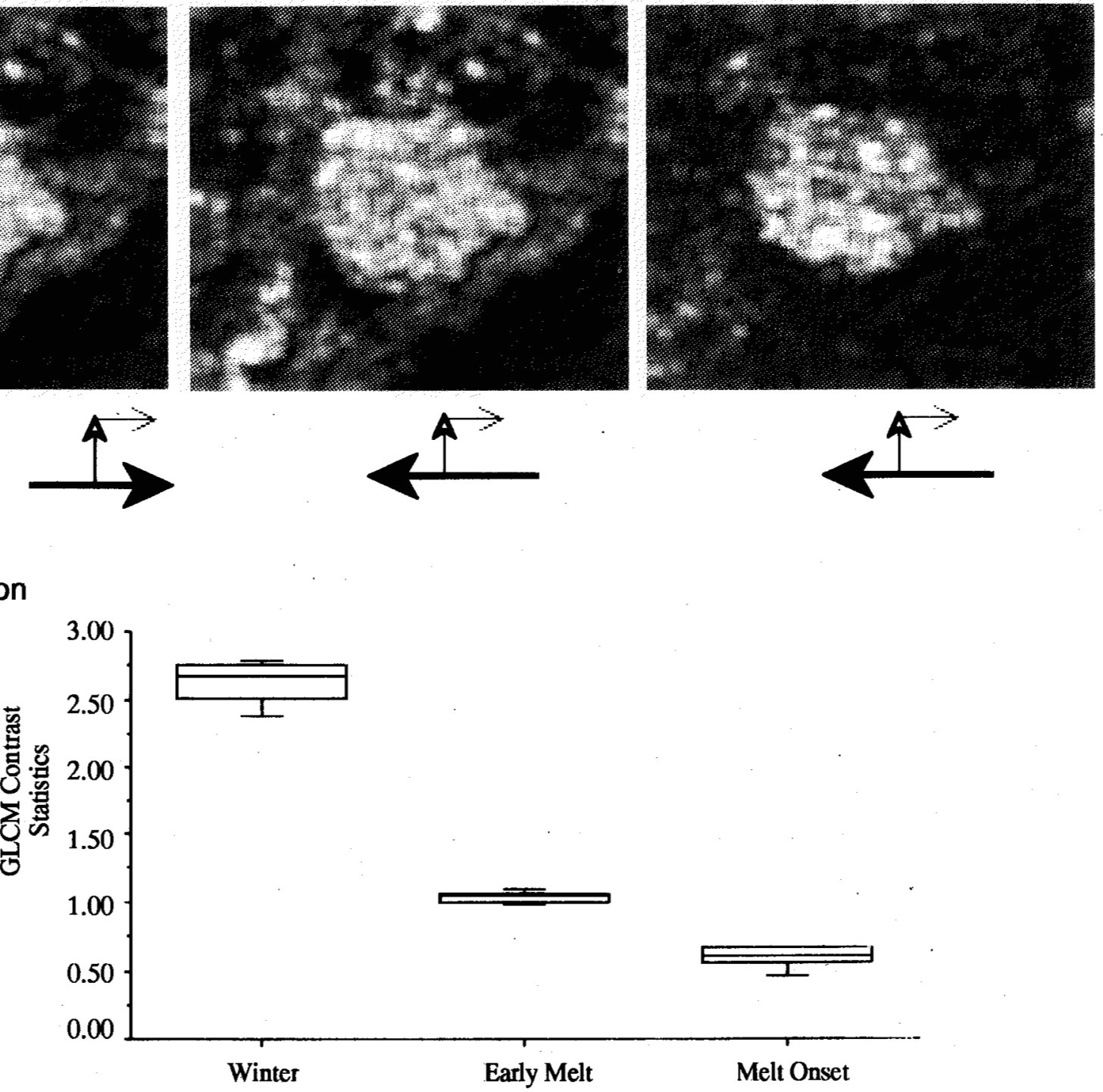
showed no distinct temporal pattern over SIMS'90. The presence of low albedo $(0.65)$ bare hummocks at the MYI site compensated for the high albedo (0.85) of deep snow cover between hummocks, resulting in a winter site albedo lower than the albedo observed over the FYI site. The effect of a fresh snowfall on the MYI site albedo on 5 June gives some indication of the high sensitivity of albedo over a multiyear ice site. When hummocks are exposed at the MYI site, the spatial variability of surface albedo increases. A fresh snowfall can greatly reduce this heterogeneity.

Spectral albedos collected over snow surfaces during SIMS'90 indicate minimal variation in reflectance throughout the visible portion of the electromagnetic spectrum.
Reflectance decreased within the near-infrared, illustrating the wavelength dependence and sensitivity of snow reflectance to phase changes within the snow cover. A temperature increase of $5.5 \mathrm{C}^{\circ}$ promoted a phase change within the snow pack from ice to liquid and vapour, which caused the associated changes in grain size (increase) and structure (rounding). Spectral albedo in the near-infrared region is most sensitive to these changes (Fig. 13) as absorption increases in near-surface layers of the snow pack. Although to a lesser degree, reduced volume scattering within the pack may also decrease albedo in the visible portions of the spectrum.

Ice Variables: Temperature profiles exhibit a general trend of increasing temperature with increasing depth (Fig. 14). The

A

\section{Tone Images HOME Site}

\section{Winter}

January 29, 1990, 12:51 hrs.
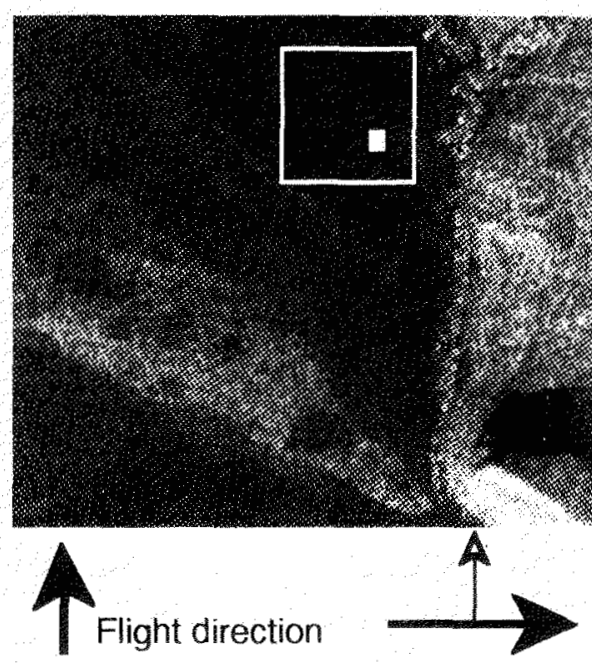

A Look direction
Early Melt

May 23, 1990, 11:35 hrs.
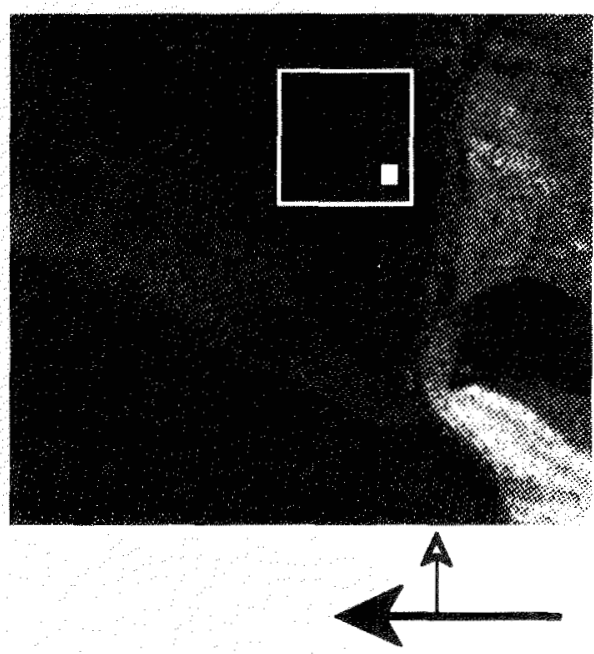

Melt Onset

June 13, 1990, 08:18 hrs.

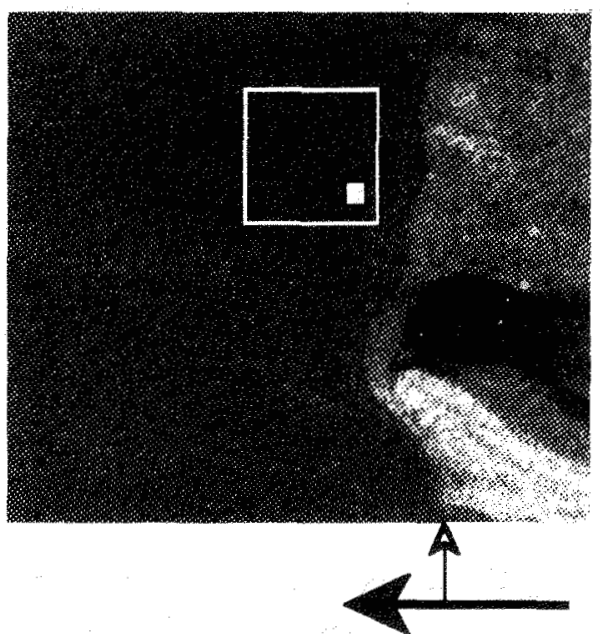

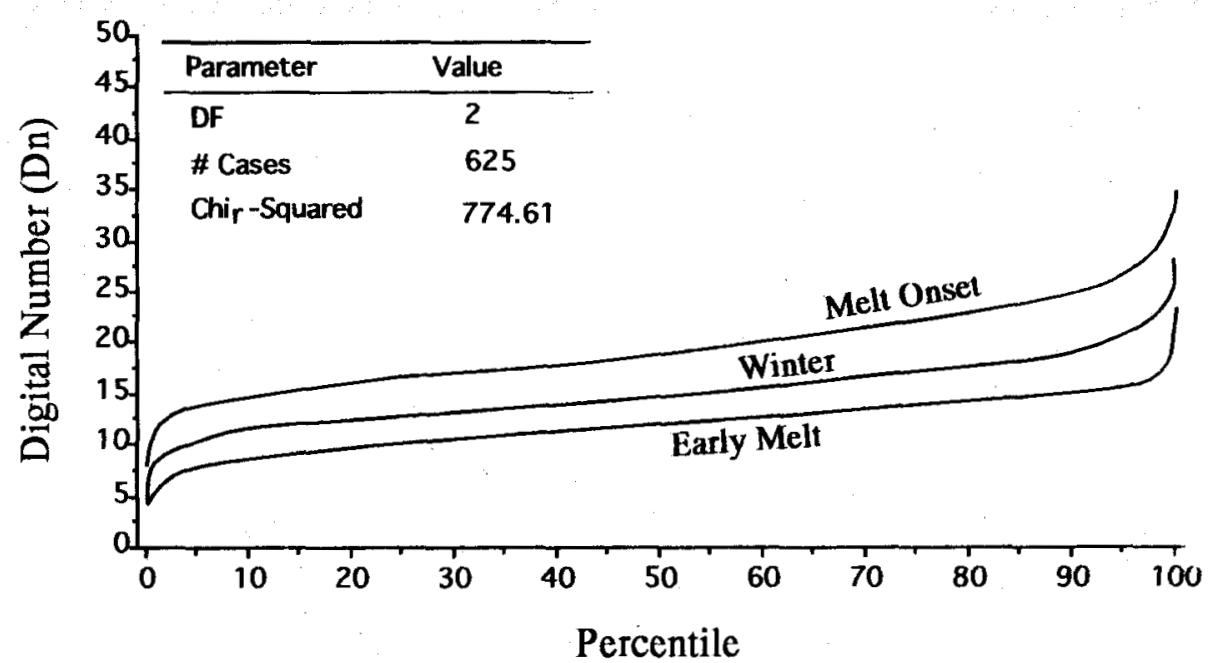

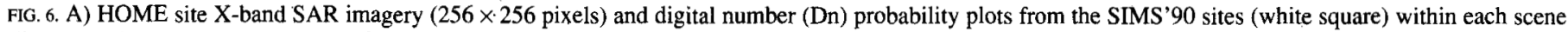

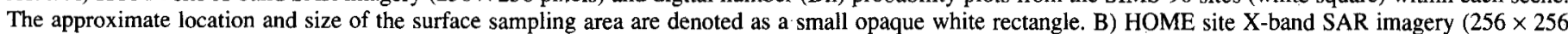

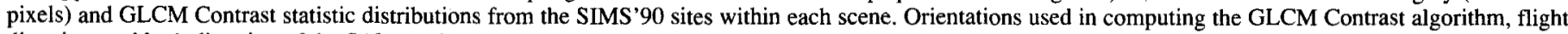
direction, and look direction of the SAR are denoted. 
profiles show deviation from a linear trend with depth, particularly towards the latter portion of the field program. This may result from a sampling limitation, caused by ambient condition contamination, or it may be a true seasonal feature; our sampling is insufficient to conclude. As we progressed through the field program and into increasing air temperatures, the ice volume mirrored this trend (Fig. 14). Spatial variation between the different sites is minimal, while the variation within sites cannot be adequately characterized due to sampling limitations.

As expected, the spatial variation of salinity is most evident between the MYI (multiyear ice) site and the two first-year ice sites (HOME and FYI; Fig. 15). The second salinity profiles at the MYI site for each of 25 May and 3 June (Fig. 15A) were taken from hummocks, while the other profiles were taken from melt ponds. The hummock profiles are much less saline than the melt pond profiles. Average surface and sub-surface salinities for all ice cores and average surface salinities from measurements made at snow pits are summarized in Table 4 . Ice surface salinities measured over the field program as part of the snow pit measurements and obtained from cores agree well with salinities typical of these ice types in the Arctic Archipelago. Surface salinities show a slight decrease as we progressed throughout the field program (Table 5). This may reflect the onset of brine drainage due to warming of the ice surface temperatures (i.e., ice surface temperatures increased from a mean of $-6.7^{\circ} \mathrm{C}$ to $-4.3^{\circ} \mathrm{C}$ over this period).

Ice surface roughness exhibited temporal variation at the first-year ice sites (HOME, FYI, and TRANSECT) over the experiment period. Average rms height $\left(\sigma_{\mathrm{h}}\right)$ was $20.7 \mathrm{~mm}$ (SD $=2.0 \mathrm{~mm}$ ) during the first half of the experiment up to 25 May

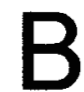

\section{Contrast Images HOME Site}

\section{Winter}

January 29, 1990, 12:51 hrs.
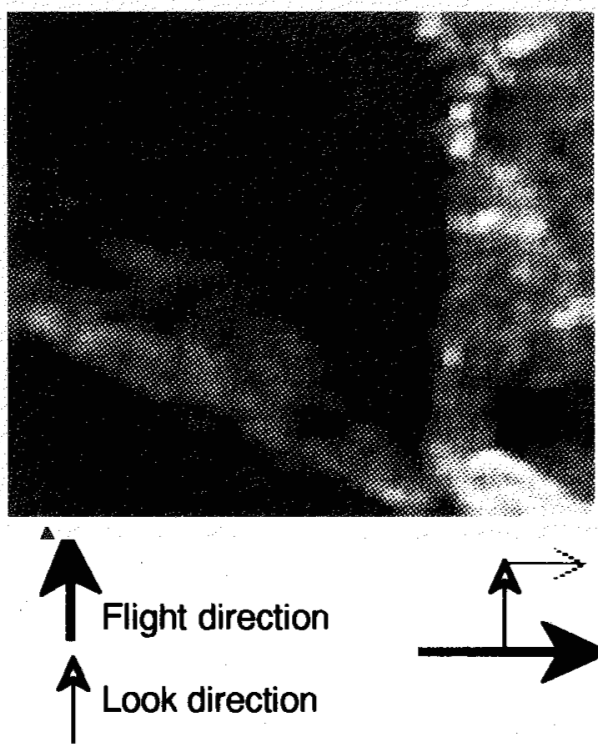

Early Melt

May 23, 1990, 11:35 hrs.
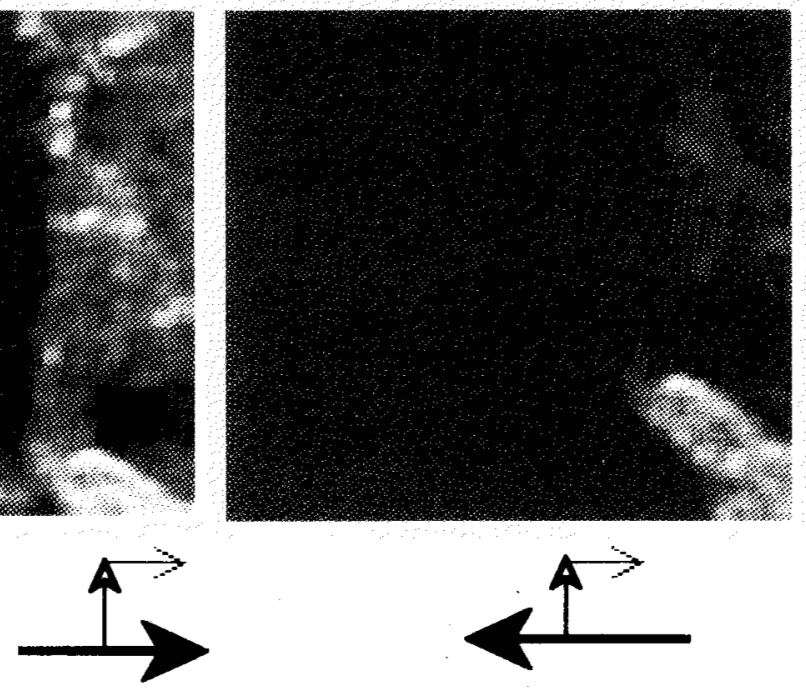
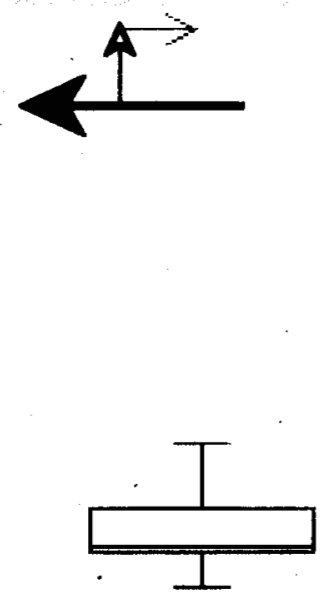

Melt Onset

June $13,1990,08: 18$ hrs.
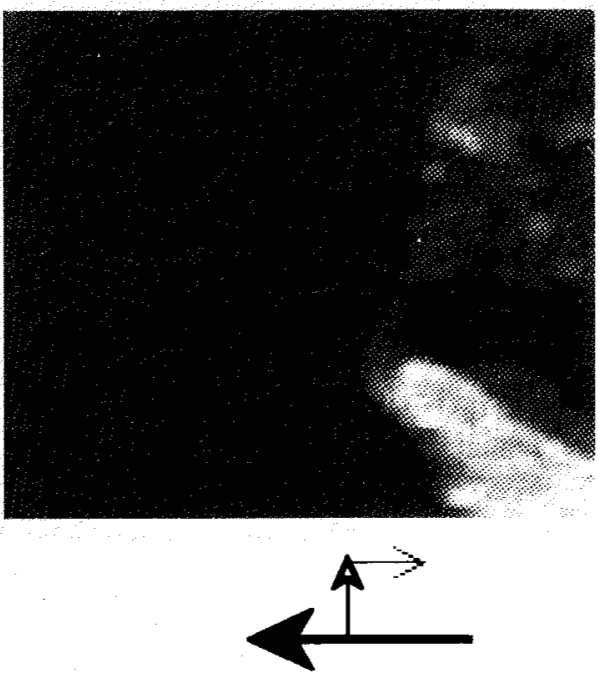<smiles>CC(O)(Cl)OCc1ccccc1</smiles>

0.40
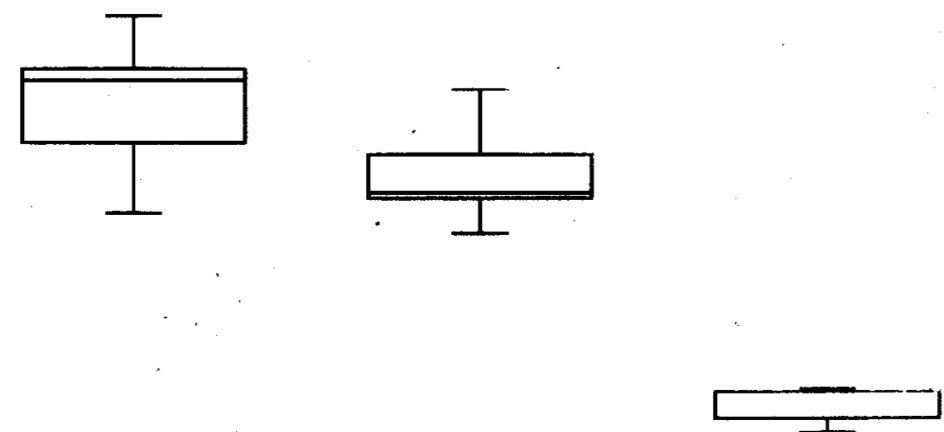

Winter

Early Melt

Melt Onset 
and $26.6(\mathrm{SD}=5.2 \mathrm{~mm})$ during the latter half. As temperatures approached $0^{\circ} \mathrm{C}$ around 27-28 May, an increase in the population of ice nodules (diameter $20-40 \mathrm{~mm}$ and height 20 $30 \mathrm{~mm}$ ) on the ice surface was observed (Paterson, 1990). The largest increase in $\sigma_{h}$, of over $12 \mathrm{~mm}$, was observed at the HOME site between 24 and 28 May. At the MYI site, rms height measured on 22 May was $24.7 \mathrm{~mm}$ and on 5 June $34.3 \mathrm{~mm}$ (melt pond surfaces). With a sample size of two, we consider this result suggestive rather than conclusive of a similar metamorphic process creating an increased surface roughness on the melt ponds as for those observed at the first-year ice sites.

\section{Spatial Variation in SAR Signatures of Sea Ice}

MYI Site - Multiyear Ice: At the MYI site $\sigma^{\circ}$ is largely a function of the two main geophysical features of the multiyear ice surface: snow-covered melt ponds and hummocks (Fig. 4D). The spatial arrangement of these two features at the MYI site created the texture pattern (Onstott et al., 1987) inherent in the winter SAR data (Fig. 5). Both melt ponds and hummocks are low in salinity and the $\varepsilon^{\prime}$ and $\varepsilon^{\prime \prime}$ of melt ponds $(\sim 3.15-\mathrm{j} 0.003)$ and hummocks $(-2.6-\mathrm{j} 0.05)$ are different (dielectric properties are for $-10^{\circ} \mathrm{C}$ at $9.3 \mathrm{GHz}$; Ulaby et al., 1986). These

A

\section{Tone Images FYI Site}

Winter

January 29, 1990, 12:51 hrs.
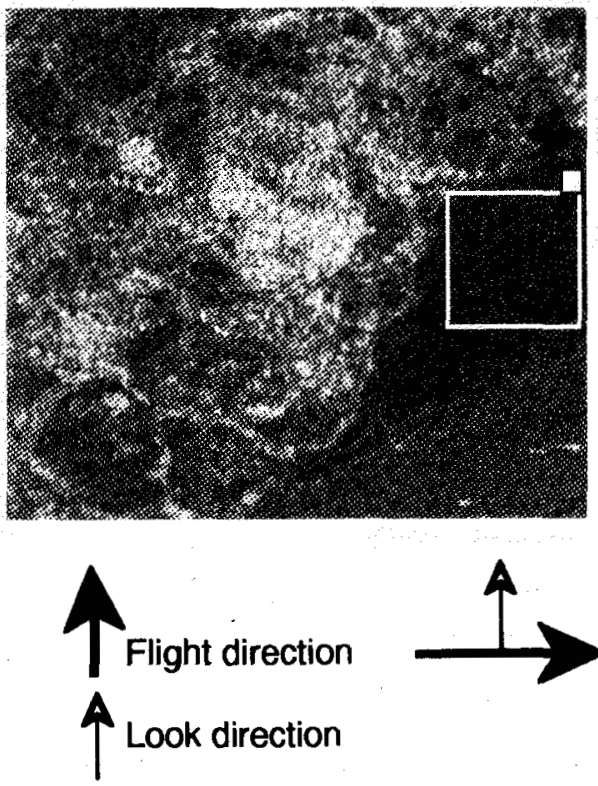

Early Melt

May 23, 1990, 11:35 hrs.
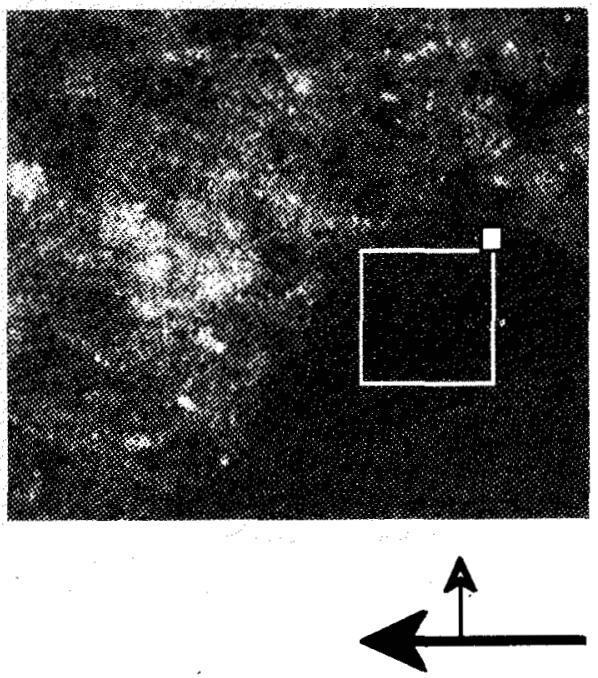

Melt Onset

June 13, 1990, 08:18 hrs.

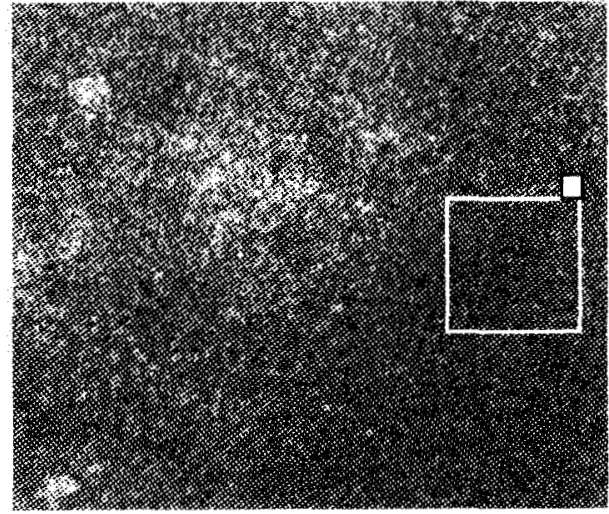

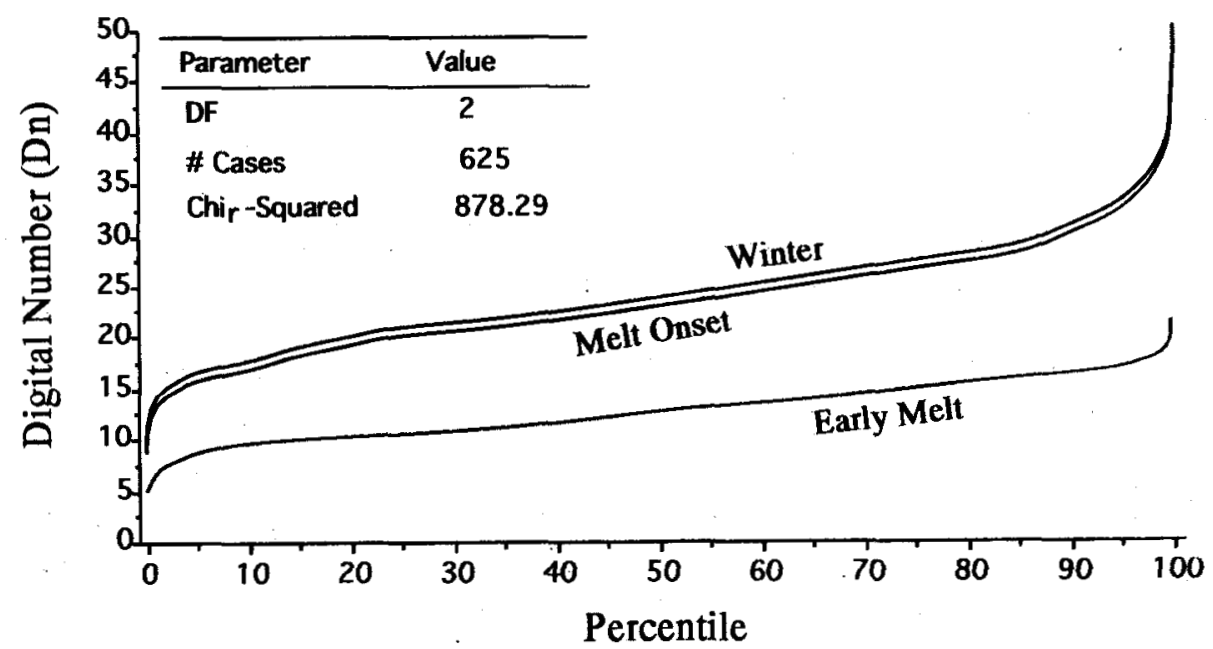

FIG. 7. A) FYI site X-band SAR imagery ( $256 \times 256$ pixels) and digital number (Dn) probability plots from the SIMS' 90 sites (white square) within each scene. The approximate location and size of the surface sampling area are denoted as a small opaque white rectangle. B) FYI site X-band SAR imagery (256 $\times 256$ pixels) and GLCM Contrast statistic distributions from the SIMS'90 sites within each scene. Orientations used in computing the GLCM Contrast algorithm, flight direction, and look direction of the SAR are denoted. 
dielectric differences, particularly $\varepsilon^{\prime \prime}$, result in different volume scattering between hummocks and melt ponds. With a deep, porous surface layer $(-30 \mathrm{~cm}$ at the MYI site), the hummocks provide considerable volume scattering at cold temperatures. The melt ponds, because of the lower loss factor, allow radiation to penetrate between 5 and $10 \mathrm{~m}$ (Ulaby et al., 1986) into the melt ponds, minimizing the amount of radiation backscattered to the SAR.

The only other SAR signature similar to a multiyear ice condition observed during SIMS'90 was attributable to a conglomerate floe (Fig. 3) consisting of small pieces of multiyear ice (10s to 100 s of metres in radius) in a matrix of highly deformed saline first-year ice. The combination of volume scattering from the multiyear ice pieces and the high surface scattering from the first-year ice roughness elements created an image texture signature similar to that of multiyear ice.

HOME Site - First-Year Ice (Early Consolidation): The winter scene from the HOME site shows little variation in tone. This is because the ice formed early, probably late September or early October. During SIMS' 90 we measured an ice surface roughness of $17.2 \mathrm{~mm}$ (rms height), which can be considered rough to an X-band radar. Due to difficulties with our surface roughness measurements, we are unable to report correlation length statistics, which are required to more thoroughly characterize the "roughness" of the surface. Scattering from this site is primarily a function of diffuse reflection from the ice surface since the snow pack is dry and the ice surface saline $(-6.0$ to $14.0 \mathrm{ppt})$.

\section{B \\ Contrast Images FYI Site}

Winter

January 29, 1990, 12:51 hrs.
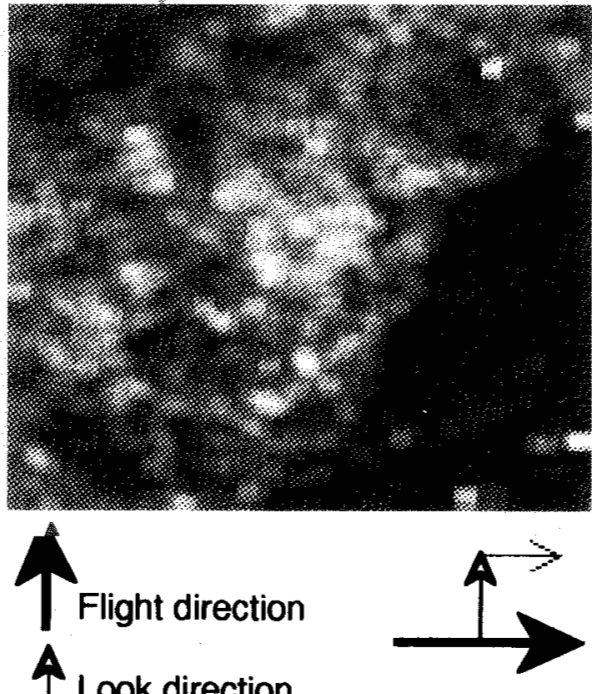

Look direction

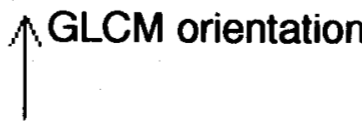

Early Melt

May 23, 1990, 11:35 hrs.
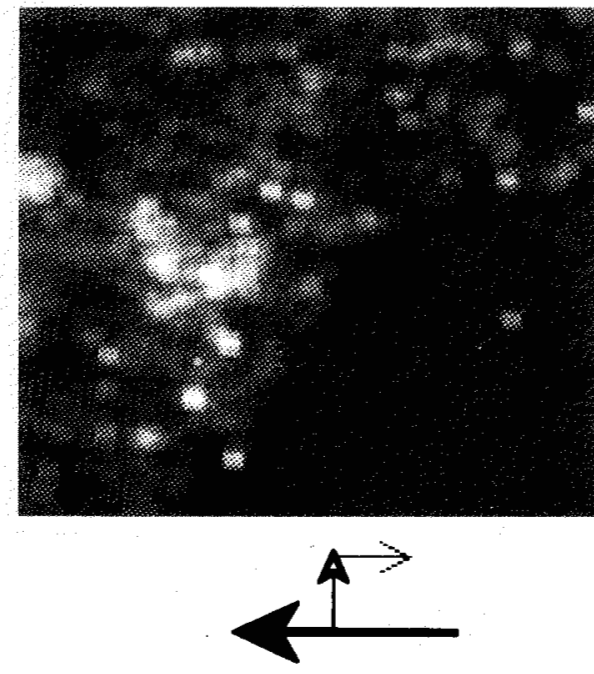

Melt Onset

June 13, 1990, 08:18 hrs.
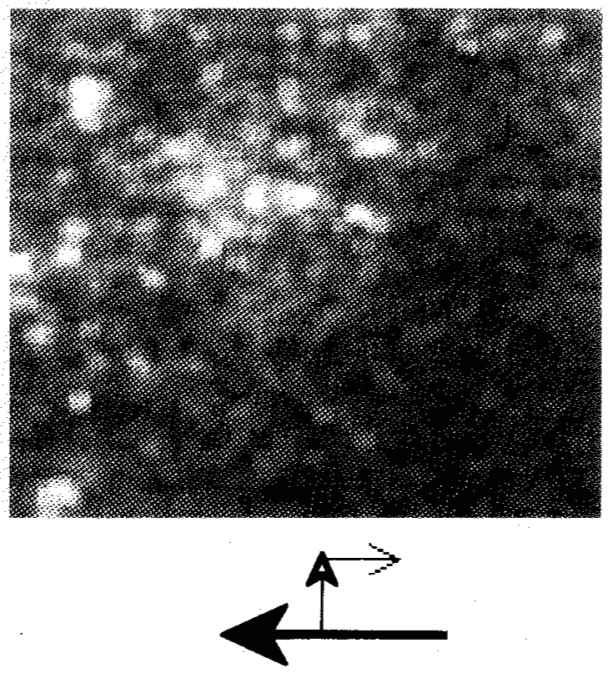

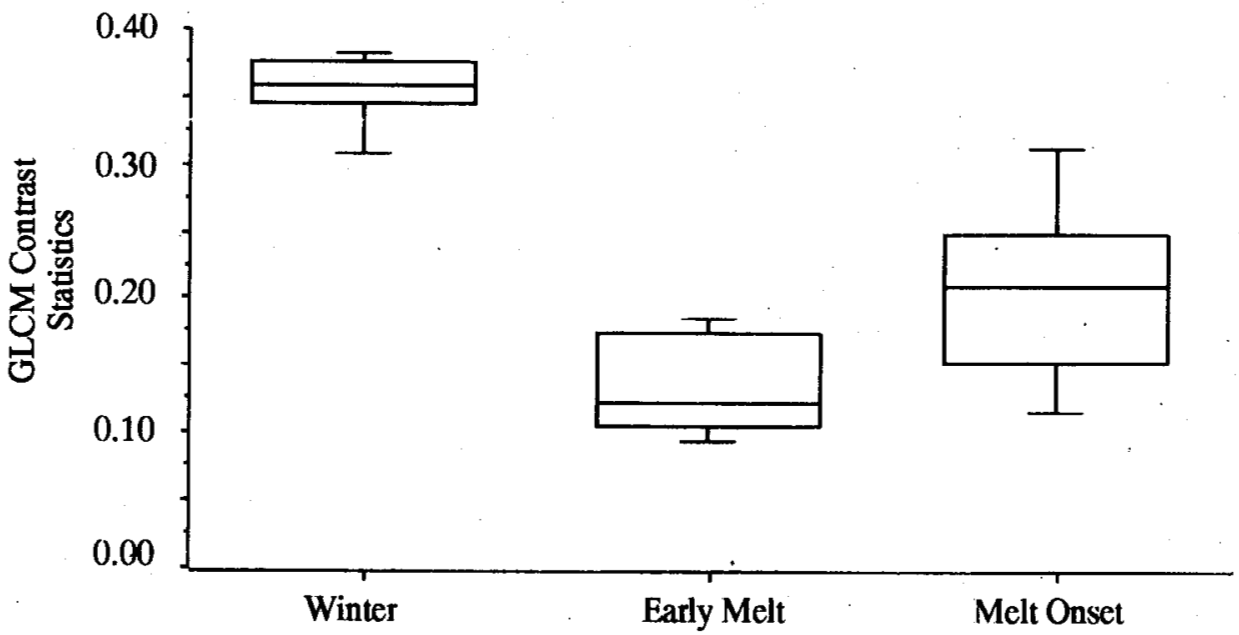




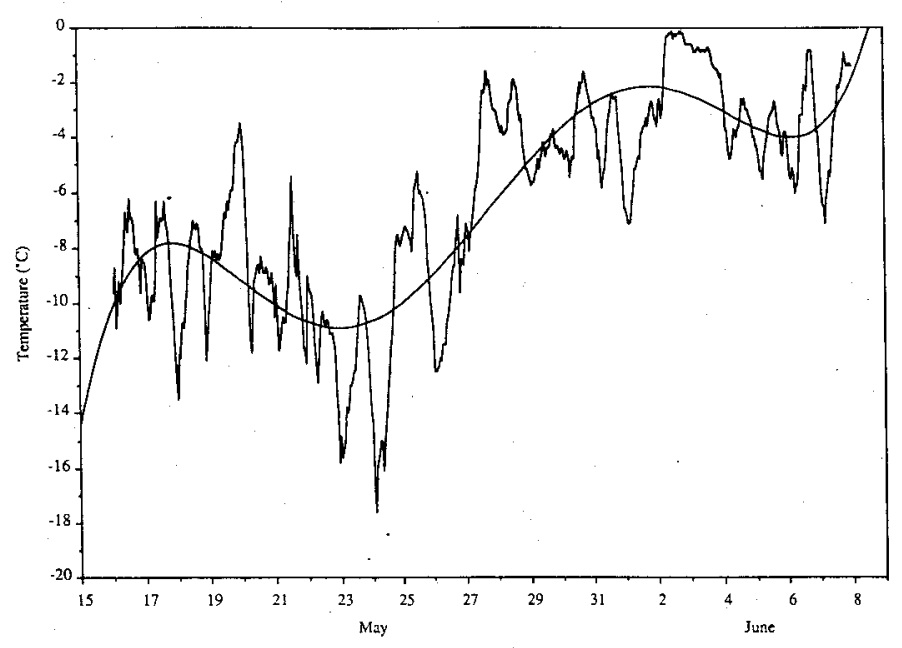

FIG. 8. Hourly air temperatures recorded at Resolute Bay weather station over SIMS'90. A polynomial least squares fit line is shown superimposed over the data.

FYI Site - First-Year Ice (Late Consolidation): The winter season scene of the FYI site has a higher magnitude and variation in scattering than the HOME site because the ice at the southeast end of Resolute Passage consolidated in late December. With this later consolidation we surmise that the ice surface salinity and roughness would be higher than at the HOME site (Table 4). These two variables combined to create the relative difference in scattering from the FYI versus HOME sites.

\section{Temporal Variation in SAR Signatures of Sea Ice}

As the season progressed we observed significant changes in both tonal and textural variations in the digital SAR data for each of the SIMS'90 surface validation sites. Data from winter, early melt, and melt onset show changes in the grey level distributions and texture GLCMs attributable to seasonal evolution of the snow-covered sea ice (Figs. 5, 6, and 7).

MYI Site - Multiyear Ice: During the early melt stage we found that the hummocks lost most of their snow due to ambient warming and metamorphism began in the deep melt pond snow pack creating the beginning of ice layers and lenses. As the water in liquid phase within the snow increased, and as diurnal variation in temperature caused changes in the crystal structure throughout the pack, the penetration depth of microwaves into the pack decreased. A convenient model [5] links microwave frequency $(\lambda)$, the permittivity of dry snow $\left(\varepsilon^{\prime}\right)$, the change in $\varepsilon^{\prime}$ due to wetness, and the dielectric loss $\left(\varepsilon^{\prime \prime}\right)$ of wet snow to compute penetration depth $(\delta p)$, following Drinkwater (1989):

$$
\delta_{p}=\frac{\lambda}{4 \pi}\left\{\left[\left(1+\left(\frac{\varepsilon^{\prime \prime}}{\varepsilon^{\prime}}\right)^{2}\right)^{\frac{1}{2}}-1\right] \frac{\varepsilon^{\prime}}{2}\right\}^{\frac{-1}{2}}
$$

where $\lambda$ is the SAR wavelength in metres and $\varepsilon^{\prime}$ and $\varepsilon^{\prime \prime}$ are the dielectric permittivity and loss. The impact of very small quantities of water on the penetration depth at $9.3 \mathrm{GHz}$ for conditions typical of the ranges measured at the MYI site results in a substantial drop in the penetration depths (Fig. 16). As the penetration depth decreased the average scattering from a snow-covered ice surface contained an increasing contribution from the snow volume. These penetration curves overestimate the penetration depth, since the scattering losses are assumed negligible in this model.
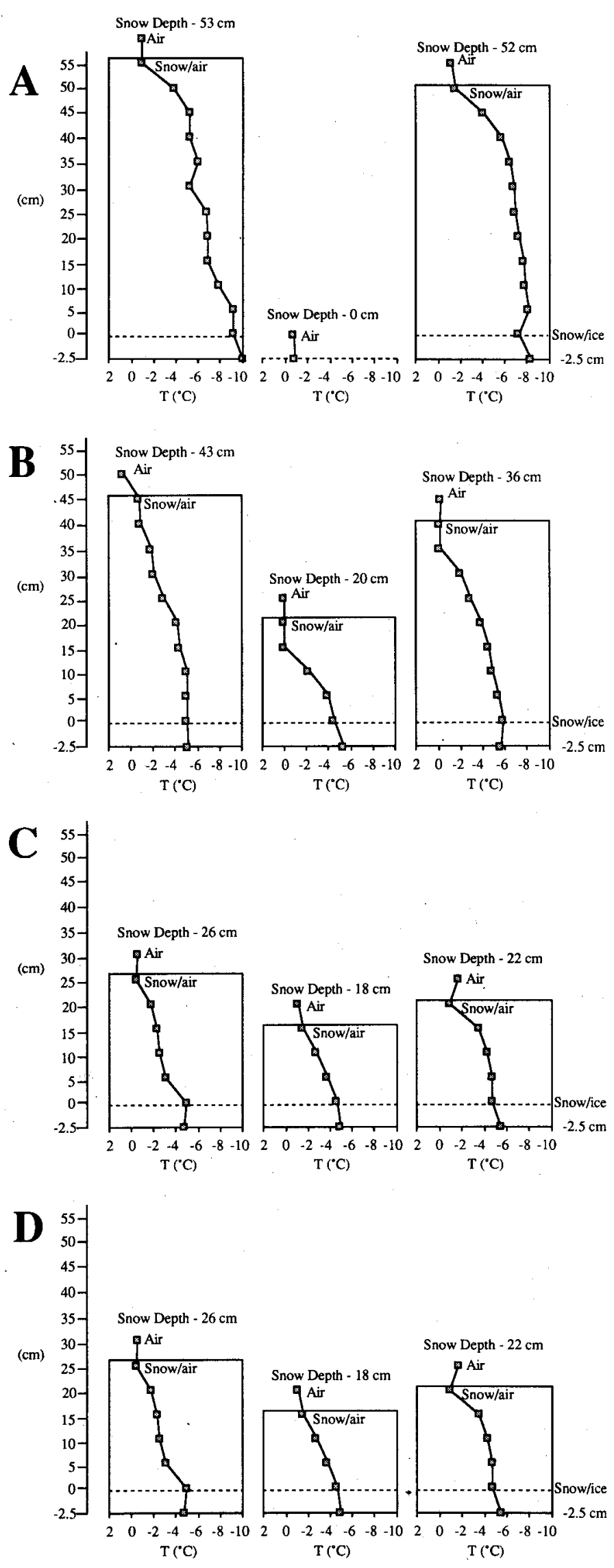

FIG. 9. Snow temperature profiles. A) MYI site from 27 May 1990; B) HOME site from 28 May 1990; C) FYI site from 29 May 1990; D) TRANSECT site from 30 May 1990. Three samples are illustrated from the available ten to show the difference in snow temperature profiles over the sampling scales employed. 
During the melt onset stage microwave penetration into the snow-covered melt ponds decreased as the metamorphism of this pack increased. Due to the high ambient temperatures, free water could occur at both the surface of snow-covered melt ponds and within the hummocks.

The spatial pattern of seasonal change in the SAR image data is evident in an overall reduction in variability of $\sigma^{\circ}$ within the MYI site, as illustrated by the percentile line plots in Figure 5A (decreasing slope of the lines). The texture measures of the MYI site show that image texture decreased over the seasonal transition. As the local variance of the MYI site decreases.(Fig. 5A), the individual $C_{i j}$ probabilities increase and the grey level contrast decreases (i.e., $\mathrm{i}-\mathrm{j}$ term in [4]; Fig. $5 \mathrm{~B})$, resulting in a net reduction in the magnitude of. [4]. This is consistent with the theory of decreasing volume scattering from the hummocks and increasing snow volume scattering from the melt ponds. It is important to note the GLCM Contrast statistics fall in the range 2.65 (winter), 1.10 (early melt) and 0.6 (melt onset) at the MYI site.

HOME Site - First-Year Ice (Early Consolidation): In the early melt stage there is a slight decrease in scattering compared with the winter season. We expect that the relative contribution of snow volume scattering increased over that of ice surface scattering during this stage because of the observed changes in snow crystal structure and due to development of a moist saline hoar layer at the base of the snow pack. Within the image data this is manifested by the inability of the radar to resolve the small- and medium-scale ridging, which was subsurface to the snow cover, immediately south and west of the HOME site as the seasons progressed from winter to early melt (Fig. 6A).

In the melt onset stage the impact of the snow cover on scattering becomes more pronounced. The increase in water volume within the snow pack causes more of the scattering signal to be attributed to either snow volume or snow surface scattering relative to ice surface scattering. Change in snow cover metamorphism is a spatially heterogeneous process. We postulate that the increased variance (larger percentile line slope) within the melt onset percentile plot of Figure 6A is a result of this heterogeneity.

The spatial pattern of seasonal change is evident as a decrease in scattering between winter and early melt and then as an increase in mean tone and variance in the melt onset season (Fig. 6A). The GLCM Contrast statistics, however, show a general decrease over the seasonal progression (Fig. 6B). This is largely due to the decrease in individual cell probabilities in the co-occurrence matrix. As the local variance of the HOME site increased due to increased volume scattering from the snow cover, the individual $\mathrm{C}_{\mathrm{ij}}$ probabilities decreased. The low initial range of digital numbers $(0-20)$ over the seasonal transition resulted in low grey level contrast in the 4 bit image (i-j in [4]). Note that the GLCM Contrast statistics fall in the range 0.3 (winter), 0.25 (early melt), and 0.05 (melt onset) at the HOME site.

TABLE 3. Snow depths over SIMS' 90 field program

\begin{tabular}{lcc}
\hline \multicolumn{1}{c}{ Site } & Average $(\mathrm{cm})$ & SD $(\mathrm{cm})$ \\
\hline MYI & 32.5 & 21.1 \\
HOME & 24.5 & 8.7 \\
FYI & 24.9 & 6.3 \\
TRANSECT & 22.0 & 7.5 \\
\hline \hline
\end{tabular}
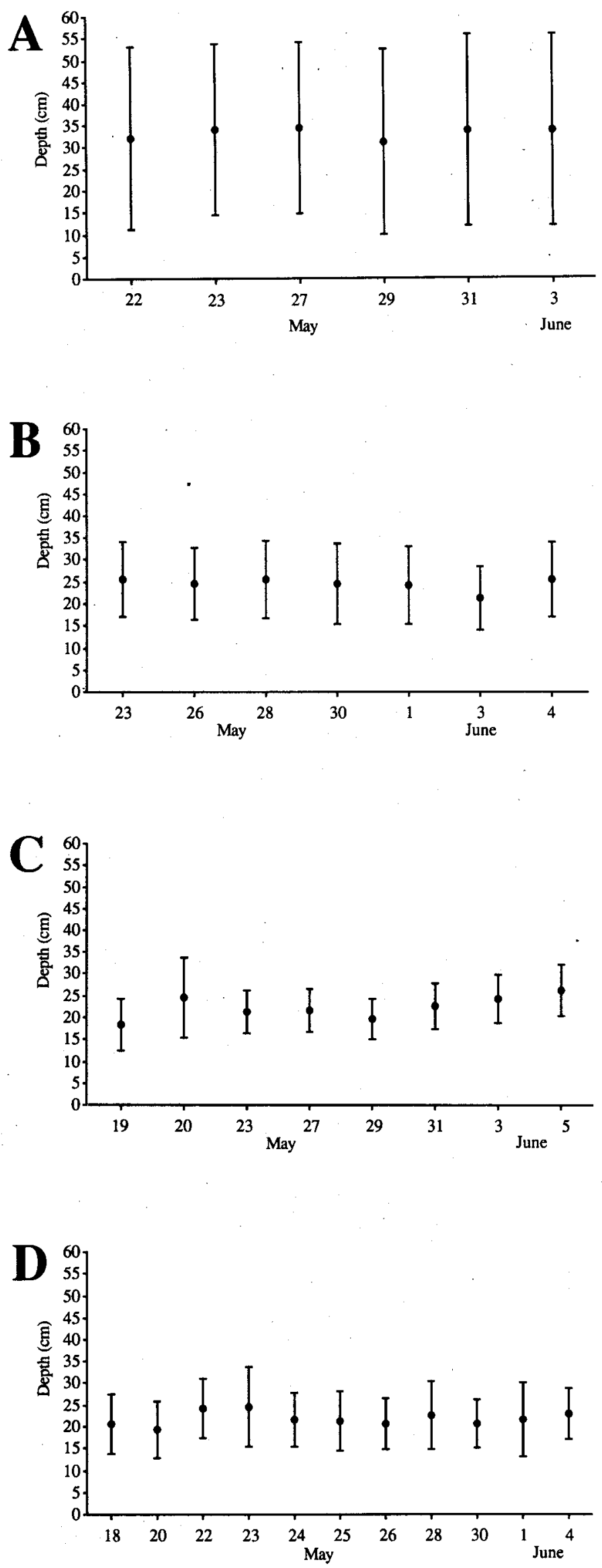

FIG. 10. Mean snow depths \pm 1 standard deviation $(\mathrm{n}=10)$. A) MYI site; B) HOME site; C) FYI site; D) TRANSECT site. 
FYI Site - First-Year Ice (Late Consolidation): In the early melt stage there is a substantial (compared with the same seasons at the HOME site) decrease in scattering relative to the winter season. We expect this reduction is largely due to thickening of the ice, which co-varies with a reduction in its bulk salinity. In the melt onset stage the impact of the snow cover on scattering becomes more pronounced. As in the case of the HOME site, this resulted in an increase in the scattering magnitude (larger Dn values) and a corresponding increase in scattering variance (increased slope of the percentile line plot).

The spatial pattern of seasonal change is evident as a decrease in scattering between winter and early melt and then an increase in mean tone and variance in the melt onset season (Fig. 7A). The GLCM Contrast boxplots (Fig. 7B) reflect the same general conditions as the HOME site, with the exception of the increased variability of the melt onset data. Note that the GLCM Contrast statistics fall in the range 0.36 (winter), 0.13 (early melt), and 0.20 (melt onset) at the HOME site. It is interesting to note that the Dn percentile line plots for winter and melt onset are nearly identical but that the GLCM contrast statistic means and variances are considerably different. Close examination of the actual GLC Matrices shows that although the mean and variance of each set are similar, the spatial pattern is considerably different. The exact sensitivities of the Contrast statistic relative to the observed changes in the spatial variations of the snow and ice geophysical properties clearly require further research.
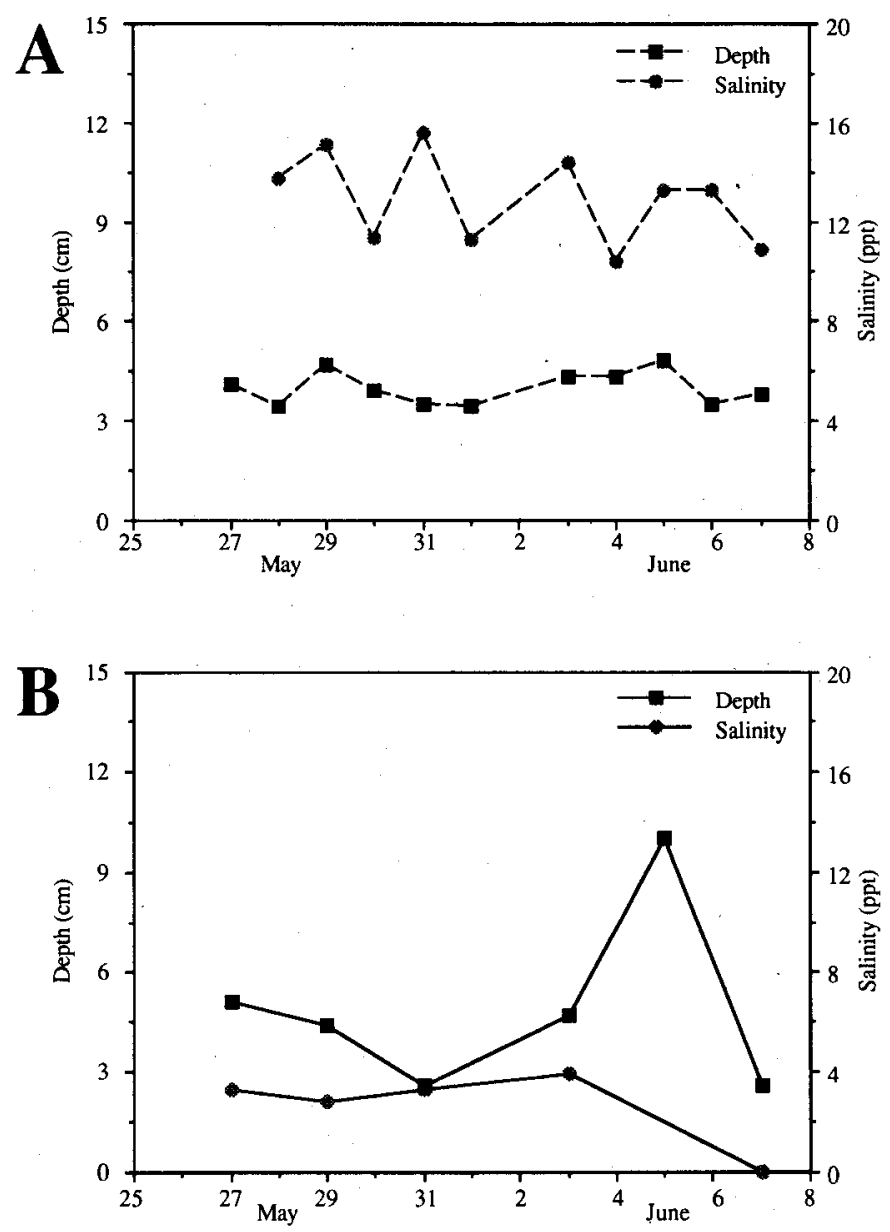

FIG. 11. Mean hoar depths and salinities. A) HOME, FYI, and TRANSECT sites; B) MYI site.

\section{Seasonal and Ice Site Texture Contrasts}

The two-way Multivariate Analysis of Variance (MANOVA) provides a good summary of the distributional differences that arise between the three seasonal and ice site factors. The MANOVA (Table 6) shows that all factor levels contain at least one distribution of the square root of the GLCM Contrast statistic [4] that is significantly different from the others (significant P-values for each level). The difference in the ice site main effects $(F-$ Ratio $=1950.09)$ is larger than for the season effect $(\mathrm{F}-\mathrm{Ratio}=590.91)$. This means that there is a greater separation of at least one of the main effects over the ice sites as compared with differences among at least one of the seasons. Examination of the pairwise main effects (Fig. 17) shows good separation of the MYI from the FYI and HOME sites during the winter season. HOME and FYI site GLCM

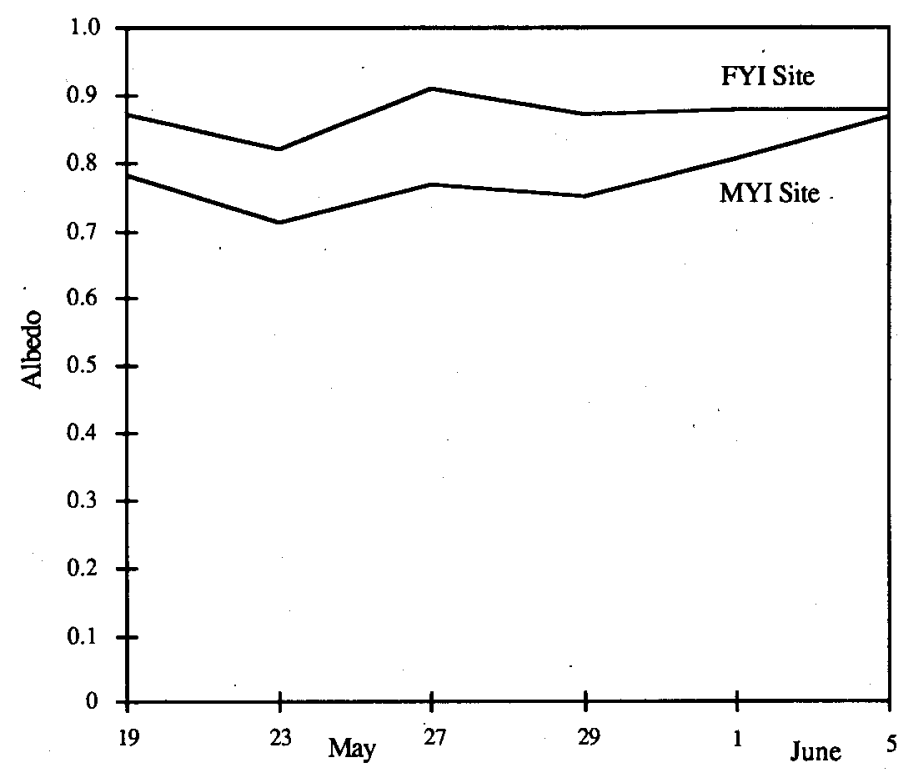

FIG. 12. Mean site albedos. MYI and FYI sites.

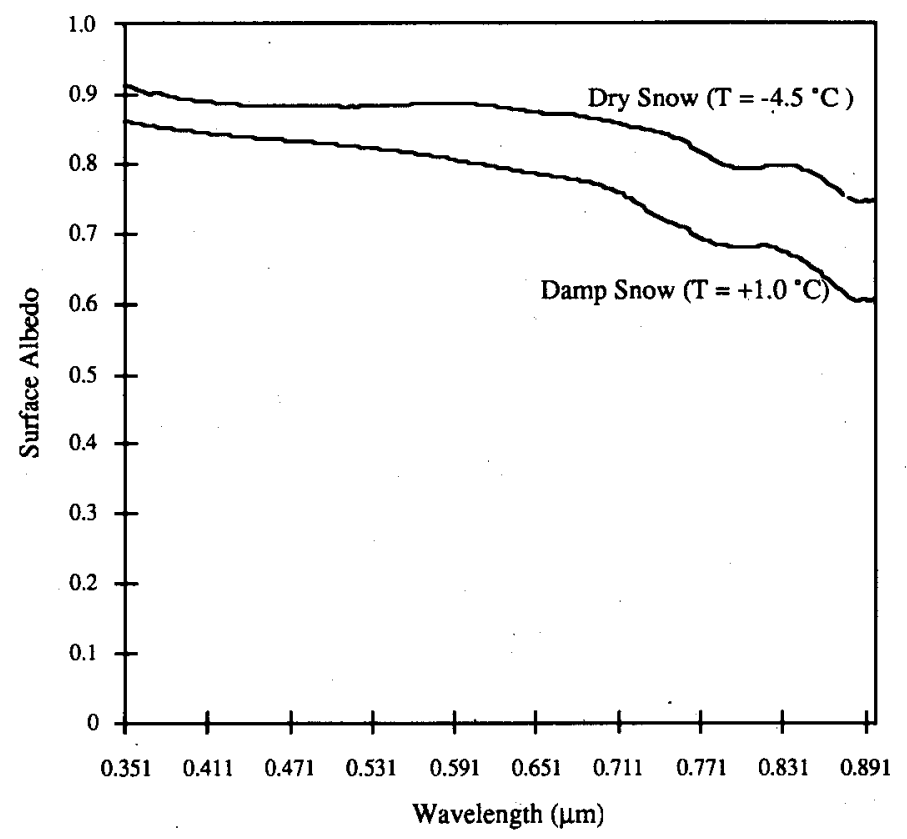

Fị. 13. Surface spectral albedo typical of dry and wet snow surfaces. 
Contrast statistic distributions are poorly separated in the winter season. In the early melt season the MYI site is separable from the HOME and FYI sites, but separation of HOME and FYI appears to be marginal. Of note in the melt onset season is the reduced separation of MYI versus FYI and the increased separability of HOME versus FYI compared with the winter season. Also note that the slope of the change between winter and early melt is much steeper for the MYI site than for either the HOME or FYI sites. This illustrates the sensitivity of the multiyear ice type to early changes in the seasonal metamorphosis of the cover. It has been observed that the surface albedo of multiyear ice also changes much more rapidly than the firstyear ice types because of the removal of snow from the hummocks early in the seasonal evolution of the snow pack.

\section{CONCLUSIONS}

The SIMS'90 experiment was conducted as the pilot study of a five-year research program. Our initial results are encouraging and were utilized in preparation for SIMS'91 (11 May to 18 June 1991). Our primary focus here has been the development of techniques whereby geophysically meaningful information can be extracted from SAR data of sea ice. The spatial and temporal sampling conducted during SIMS' 90 provides the fundamental conditions required for development of these algorithms. The most important results presented here
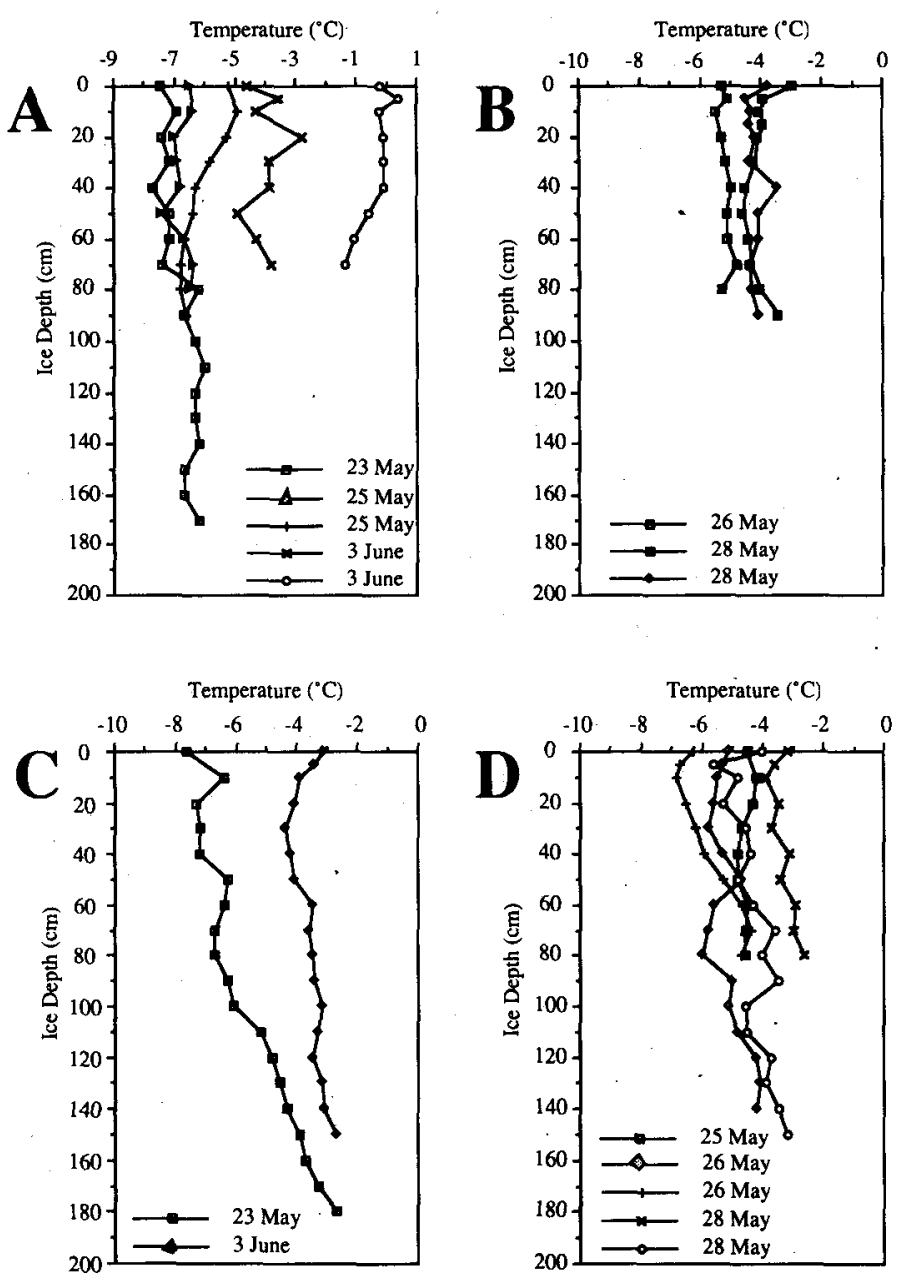

FIG. 14. Ice core temperature profiles. A) MYI site; B) HOME site; C) FYI site; D) TRANSECT site. can be summarized in the context of their geophysical and remote sensing significance.

Geophysically, the spatial and temporal variability observed within and between the ice sites is driven by increased solar insolation resulting from the approaching solstice. Thermodynamically, the transfer of enthalpy from the atmosphere to the - ice volume results in an increasingly isothermal temperature
Salinity (ppt)

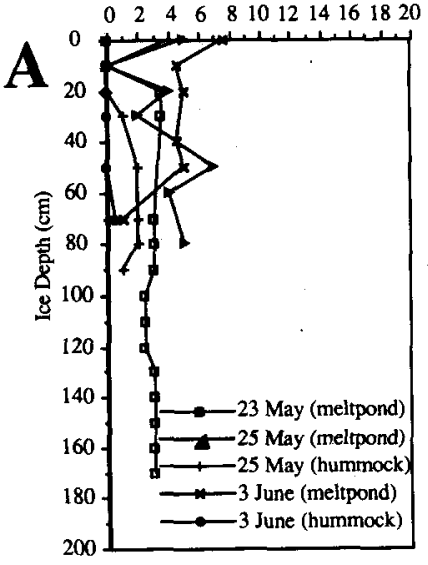

Salinity (ppt)

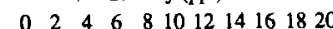

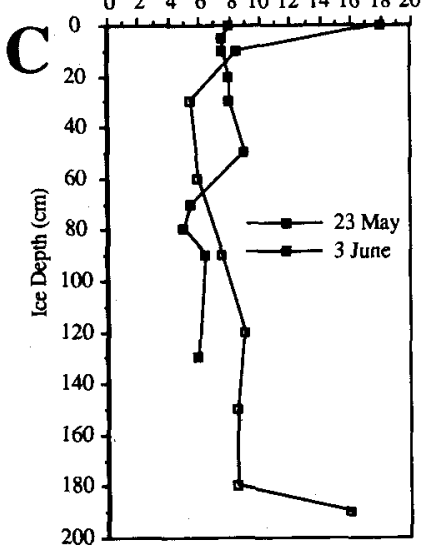

Salinity (ppt)

$02.4 \quad 6 \quad 8101214161820$

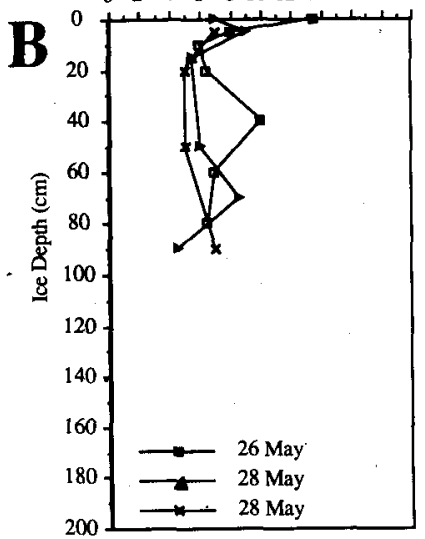

Salinity (ppt)

4468101214161820

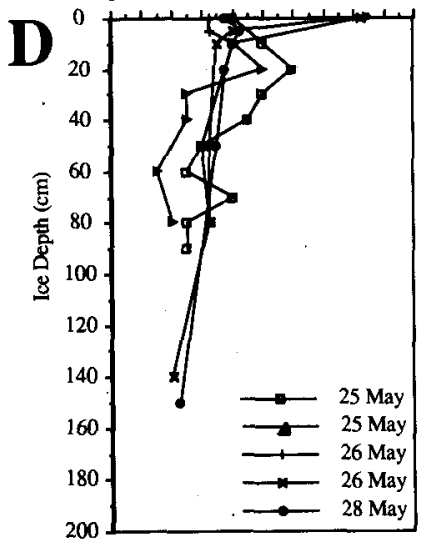

FIG. 15. Ice core salinity profiles. A) MYI site; B) HOME site; C) FYI site; D) TRANSECT site.

TABLE 4. Average salinity values

\begin{tabular}{lccc}
\hline \hline Site & $\begin{array}{c}\text { Surface sal. } \\
\text { (Cores) (ppt) }\end{array}$ & $\begin{array}{c}\text { Sub-surface sal. } \\
\text { (Cores) (ppt) }\end{array}$ & $\begin{array}{c}\text { Surface sal. } \\
\text { (Snow pits) (ppt) }\end{array}$ \\
\hline MYI & 3.3 & 2.6 & 1.9 \\
HOME & 10.3 & 6.7 & 6.8 \\
FYI & 13.0 & 7.8 & 9.3 \\
TRANSECT & 9.7 & 7.0 & 8.9 \\
\hline \hline
\end{tabular}

TABLE 5. Temporal variation in ice surface salinities from snow pits

\begin{tabular}{lccc}
\hline \hline Site & $\begin{array}{c}\text { Mean (SD) } \\
\text { 16-23 May (ppt) }\end{array}$ & $\begin{array}{c}\text { Mean (SD) } \\
\text { 24-31 May (ppt) }\end{array}$ & $\begin{array}{c}\text { Mean (SD) } \\
\text { 1-7 June (ppt) }\end{array}$ \\
\hline MYI & $1.7(1.7)$ & $2.3(3.6)$ & $1.5(2.7)$ \\
HOME & $8.1(3.5)$ & $7.7(2.9)$ & $5.2(2.2)$ \\
FYI & $10.5(2.0)$ & $10.1(2.0)$ & $6.8(1.4)$ \\
TRANSECT & $11.7(3.7)$ & $7.8(2.4)$ & $6.6(3.1)$ \\
\hline \hline
\end{tabular}




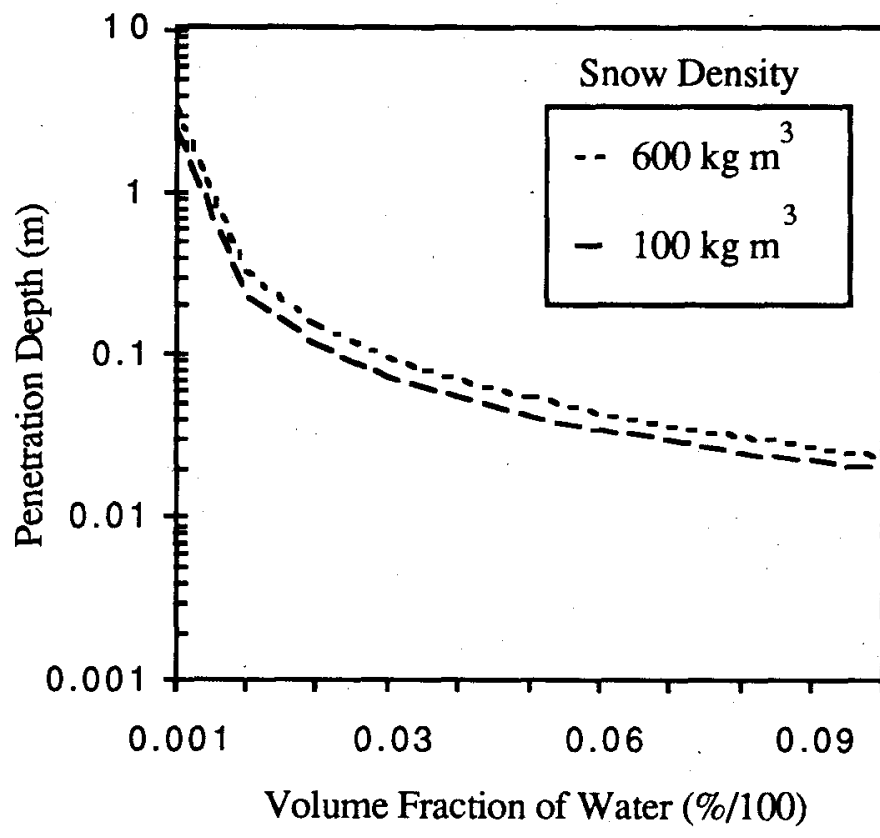

FIG. 16. Relationship between microwave penetration depth $(\delta p)$, volume fraction of water $(\mathrm{Wv})$, and frequency $(\lambda)$ at two snow densities.

profile and in the process causes many structural changes within the snow pack. Changes in crystal size and shape are retained once the atmospheric temperatures decrease, thereby recording a thermal history. Radiatively the conditions we experienced showed little temporal variation primarily because only marginal increases in free water content were observed. The spatial variation in integrated climatological albedo over the MYI site illustrates the importance of snow cover over these ice conditions. Thermal gradients were also affected by a surprisingly thin snow cover on hummocks. At zero snow depths the hummock temperatures reflected atmospheric temperatures (Fig. 9A). Addition of $<1 \mathrm{~cm}$ fresh snow cover caused hummock surface temperatures to drop by $5-7 \mathrm{C}^{\circ}$, compared with ambient temperatures. This thin layer of insulating snow cover caused the hummock surface (actually $2.5 \mathrm{~cm}$ into the hummock) to reflect the core temperature of the MYI site. The principal limitation of the SIMS' 90 field sampling was in not collecting a sufficiently long temporal record to completely characterize the seasonal variations from winter to advanced melt conditions.

Within a remote sensing context, SIMS'90 SAR data indicate that spatial variability (winter season) is a function of ice density, ice surface roughness, and possibly snow depth. The distribution of melt ponds versus hummocks gives rise to the unique textures of multiyear ice. Confusion can occur with

TABLE 6. Two-way Multivariate Analysis of Variance (MANOVA) of GLCM Contrast statistics at three levels of season (winter, early melt, melt onset) and three levels of ice site (MYI, HOME, FYI)

\begin{tabular}{lcrrrr}
\hline Source & SSE & DF & MSE & F-ratio & P-value \\
\hline Season & 2.91 & 2 & 1.45 & 590.91 & 0.0001 \\
Ice site & 9.60 & 2 & 4.80 & 1950.09 & 0.0001 \\
Interaction of season & & & & & \\
$\quad$ and ice type & 1.70 & 4 & 0.42 & 172.29 & 0.0001 \\
Residual error & 0.20 & 81 & 0.002 & & \\
\hline \hline
\end{tabular}

*Analysis is based on the square root transform of the GLCM Contrast statistics.

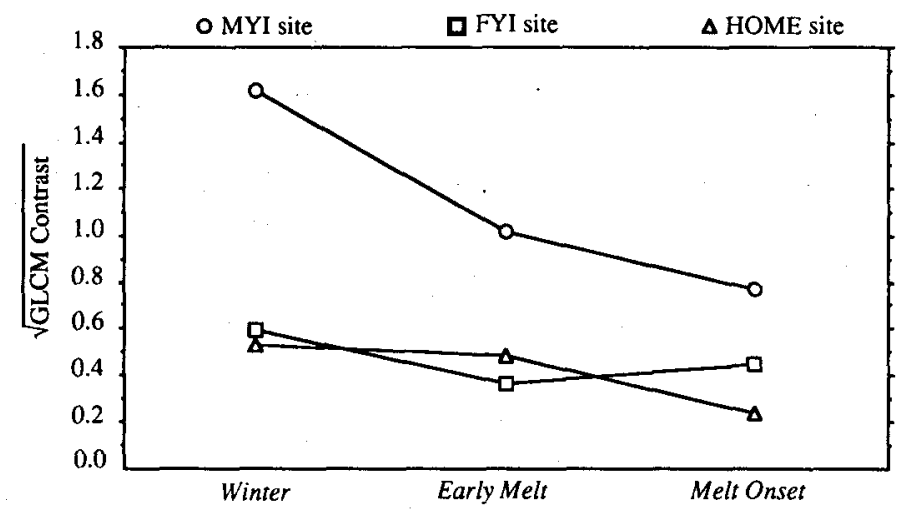

FIG. 17. Main factor interaction effects from the analysis of variance of ice site and season.

conglomerates of rubble first-year and multiyear ice. Firstyear ice surface roughness is the principal factor determining scattering to the STAR-2 radar. Roughness elements greater than $5 \mathrm{~cm}$ in height above the mean surface level can be expected to produce a detectable SAR signature. Confusion can occur between the orientation of the scattering elements and their height above the average ice surface. Although modelling results suggest the contribution of snow cover is negligible in specification of $\sigma^{\circ}$ (Kim et al., 1984; Winebrenner $e t$ al., 1989), scatterometer observations (Onstott et al., 1982; Onstott and Shuchman, 1988; Bredow and Gogennini, 1990) have shown that a winter snow cover on thick first-year ice substantially increased the backscattering coefficient. A general result is that the smoother the ice type the larger the impact a snow cover will have. Results of the impact of snow cover in winter conditions during SIMS' 90 are inconclusive.

Temporal variation in SAR signatures of multiyear and the two forms of first-year ice are probably the most significant result of these analyses. Since multiyear ice is sensitive to the seasonal transitions observed during SIMS'90, it may operate as an indicator of the metamorphic changes associated with these seasonal transitions. The geophysical and biophysical significance of this result is considerable and includes the potential to monitor the increase in free water content of the snow cover with the onset of melt. This knowledge would be useful in all surface radiative flux analyses, since climatological shortwave radiation and Photosynthetically Active Radiation (PAR) are linked with the amount of water in liquid and vapour phase within the snow pack. It is also interesting to note that the early consolidation first-year ice site (HOME) provided sensitivities that were somewhat seasonally opposed to those of the MYI site (e.g., sensitive to the later seasonal transitions of winter versus melt onset and early melt versus melt onset; Fig. 17). Depending on the interannual consistency of this result, different ice conditions may be exploited to more fully monitor the seasonal metamorphism inherent in the transition from winter to advanced melt.

The results presented here are limited to a sample of the range of variations one can expect over the transition from winter to melt onset. Our surface sampling was, unfortunately, stopped short of conditions we would consider completely within the melt onset season. We were also unable to make detailed measurements of the geophysical properties of the snow cover coincident with the extinction and reflection of shortwave electromagnetic radiation. These measurements are required, coincident with SAR observations, if the concept of 
SAR monitoring of the seasonal evolution of a snow-covered sea ice volume is to be fully realized.

\section{ACḰNOWLEDGEMENTS}

The contributions of the University of Waterloo SIMS'90 group, Sean Reddan, John Parent, and Doug Johnson, are gratefully acknowledged. Data from Scott Paterson and Karen Garrity, obtained during SIMS'90, are used in this report. The SIMS program is undertaken with support from a variety of agencies, including a Centre of Excellence grant from the Province of Ontario and an NSERC (Natural Sciences and Engineering Research Council) Operating Grant, both to E. LeDrew. Chuck Livingstone provided valuable guidance in comparing the uncalibrated STAR-2 data.

\section{REFERENCES}

BARBER, D.G. 1989. Texture measures for SAR sea ice discrimination: An evaluation of univariate statistical distributions. ISTS-EOL-TR89-005. Waterloo: Technical Report Series, Earth Observations Laboratory, Institute for Space and Terrestrial Science, and the Department of Geography, University of Waterloo. $56 \mathrm{p}$.

1990. Science issues of a seasonally varying snow covered sea ice surface: The SIMS SAR surface validation experiment. ISTS-EOL-SIMSTR90-003. Waterloo: Technical Report Series, Earth Observations Laboratory, Institute for Space and Terrestrial Science, and the Department of Geography, University of Waterloo. 75 p.

BARBER, D.G., and LeDREW, E.F. 1991. SAR sea ice discrimination using texture statistics: A multivariate approach. Photogrammetric Engineering and Remote Sensing 57(4):385-395.

BARBER, D.G., JOHNSON, D., and LeDREW, E.F. 1991. Measuring climate state variables from SAR images of sea ice. The SIMS SAR Validation Site in Lancaster Sound. Arctic 44 (Supp. 1):108-121.

BREDOW, J.W., and GOGENNINI, S. 1990. Comparison of measurements and theory for backscatter from bare and snow-covered saline ice. IEEE Transactions on Geoscience and Remote Sensing 28(4):456-463.

BUTLER, D.M. 1987. From pattern to process: The strategy of the Earth Observing System. Report of the EOS Science Steering Committee (NASA), Vol. II. $140 \mathrm{p}$.

DRINKWATER, M.R. 1989. LIMEX'87 ice surface characteristics: Implications for C-band SAR backscatter signatures. IEEE Transactions on Geoscience and Remote Sensing 27(5):501-513.

DUNBAR, M.J. 1981. Physical causes and biological significance of polynyas and other open water in sea ice. In: Stirling, I., and Cleator, H., eds. Polynyas in the Canadian Arctic. Edmonton: Environment Canada, Canadian Wildlife Service. Occasional Paper Number 45. 29-43.

GARRITY, C. 1990. Snow pack properties. In: Flett, D.G., De Abreu, R.A., Barber, D.G., and. LeDrew, E.F., eds. SIMS'90 data report. ISTS-EOLSIMS-TR90-002. Waterloo: Earth Observations Laboratory, Institute for Space and Terrestrial Science, and the Department of Geography, University of Waterloo, 5.2.1-5.2.7.

GARRITY, C., and BURNS, B. 1988. Electrical and physical properties of snow in support of BEPERS-88. Technical Report MWG 88-11. North York, Ontario: York University. $65 \mathrm{p}$.

HARALICK, R.M., SHANMUGAN, K., and DINSTEIN, I. 1973. Textural features for image classification. IEEE Transaction on Systems, Man, and Cybernetics 6:610-621.

KIM, Y.S., ONSTOTT, R.G., and MOORE, R.K. 1984. The effect of a snow cover on microwave backscatter from sea ice. IEEE Journal of Oceanic Engineering OE-9(5):383-388.

LeDREW, E.F. 1990. Influence of polar regions on climate variability and change. In: Nierenberg, W.A., ed. Encyclopedia of Earth System Science. New York: Academic Press.

LIVINGSTONE, C.E., ONSTOTT, R.G., ARSENAULT, L.D., GRAY, A.L., and SINGH, K.P. 1987. Microwave sea-ice signatures near the onset of melt. IEEE Transactions on Geoscience and Remote Sensing GE-25(2): 174-187.

ONSTOTT, R.G., and SHUCHMAN, R.A. 1988. Radar backscatter of sea ice during winter. Proceedings of IGARSS ' 88 Symposium, Edinburgh, Scotland, 13-16 September 1988.

ONSTOTT, R.G., GRENFELL, T.C., MATZLER, C., LUTHER, C.A., and SVENDSEN, E.A. 1987. Evolution of microwave sea ice signatures during early summer and midsummer in the marginal ice zone. Journal of Geophysical Research 92(C7):6825-6835.

ONSTOTT, R.G., MOORE, R.K., GOGENNINI, S., and DELKER, C. 1982. Four years of low-altitude sea ice broad-band backscatter measurements. IEEE Journal of Oceanic Engineering OE-7(1):44-50.

PATERSON, J.S. 1990. Micro-scale surface roughness. In: Flett, D.G., De Abreu, R.A., Barber, D.G., and LeDrew, E.F., eds. SIMS'90 data report. ISTS-EOL-SIMS-TR90-002. Waterloo: Earth Observations Laboratory, Institute for Space and Terrestrial Science, and the Department of Geography, University of Waterloo. 5.4.1-5.4.14.

STIRLING, I. 1980. The biological importance of polynyas in the Canadian Arctic. Arctic 33:303-315.

ULABY, F.T., MOORE, R.K., and FUNG, A.K. 1986. Microwave remote sensing: Active and passive. Vol III. Massachusetts: Addison-Wesley. Publishing Company. $1098 \mathrm{p}$.

WINEBRENNER, D.P., TSANG, L., WEN, B., and WEST, R. 1989. Sea ice characterization measurements needed for testing of microwave remote sensing models. IEEE Journal of Oceanic Engineering 14(2): 149-158.

WILKINSON, L. 1989. SYSTAT: The system for statistics. Evanston, IL: SYSTAT, Inc. 638 p. 